\title{
Post-Transcriptional Modifications of Conserved Nucleotides in the T-Loop of tRNA: A Tale of Functional Convergent Evolution
}

\author{
Martine Roovers ${ }^{1}$, Louis Droogmans ${ }^{2}$ and Henri Grosjean ${ }^{2, *}$ \\ 1 Labiris, Avenue E. Gryson 1, 1070 Bruxelles, Belgium; mroovers@spfb.brussels \\ 2 Laboratoire de Chimie Biologique, Université Libre de Bruxelles (ULB), Labiris, Avenue E. Gryson 1, \\ 1070 Bruxelles, Belgium; louis.droogmans@ulb.be \\ * Correspondence: henri4g@me.com
}

check for updates

Citation: Roovers, M.; Droogmans,

L.; Grosjean, H. Post-Transcriptional Modifications of Conserved Nucleotides in the T-Loop of tRNA: A Tale of Functional Convergent Evolution. Genes 2021, 12, 140. https://doi.org/10.3390/ genes12020140

Academic Editor: Stefanie Kellner Received: 29 December 2020

Accepted: 20 January 2021

Published: 22 January 2021

Publisher's Note: MDPI stays neutral with regard to jurisdictional claims in published maps and institutional affiliations.

Copyright: (c) 2021 by the authors. Licensee MDPI, Basel, Switzerland. This article is an open access article distributed under the terms and conditions of the Creative Commons Attribution (CC BY) license (https:// creativecommons.org/licenses/by/ $4.0 /)$.

\begin{abstract}
The high conservation of nucleotides of the T-loop, including their chemical identity, are hallmarks of tRNAs from organisms belonging to the three Domains of Life. These structural characteristics allow the T-loop to adopt a peculiar intraloop conformation able to interact specifically with other conserved residues of the D-loop, which ultimately folds the mature tRNA in a unique functional canonical L-shaped architecture. Paradoxically, despite the high conservation of modified nucleotides in the T-loop, enzymes catalyzing their formation depend mostly on the considered organism, attesting for an independent but convergent evolution of the post-transcriptional modification processes. The driving force behind this is the preservation of a native conformation of the tRNA elbow that underlies the various interactions of tRNA molecules with different cellular components.
\end{abstract}

Keywords: tRNA; T-loop; nucleotide modifications; evolution

\section{Introduction}

Transfer RNAs play a central role in deciphering the genetic code during the complex multistep translation process. To fulfil this main cellular function, each isoacceptor species has to be sufficiently distinct to serve as substrate for a large array of specific proteins and enzymes such as modification enzymes and cognate aminoacyl-tRNA synthetase (identity problem), while it also has to be sufficiently identical to serve in a uniform way for interactions with other partners such as elongation/initiation factors and with elements of the ribosome during the various steps of the translation process (conformity problem). To this end, these small RNA molecules have to fold into a uniform 3D-conformation, the so-called L-shaped architecture (reviewed in [1,2]). Conservation of certain nucleotides at key positions combined with chemical alterations of selected nucleotides catalyzed by specific enzymes during the post-transcriptional maturation processes contribute to solve both the identity and conformity problems of the tRNA repertoire within a given cell. These also allow to regulate tRNA plasticity according to the physiological conditions of the cell (especially the growth temperature) and fine-tune their interactions with the various cellular components of the translation machinery (reviewed in $[3,4]$ ). Notice, a few metazoan mitochondrial tRNAs lack the D-or T-arm and contain less modified nucleotides as the cytoplasmic counterparts. However, based on computer simulations, the overall L-shaped conformation of these "truncated" tRNAs appears to be maintained through combinatorial networks of alternative tertiary interactions (for details see [5,6]). These atypical tRNAs will not be considered in this review.

Here, we examine the structural parameters that allow fully mature cytoplasmic tRNAs from different origins (Bacteria, Eukarya, and Archaea) to adopt a universal L-shaped three-dimensional structure. Particularly important is the remarkable conservation of nucleotides (modified or not) at each of the 7 positions of the T-loop. A few nucleotides of the T-loop also specifically interact with a few conserved bases of the D-loop. The resulting L-shaped tRNA tertiary structure is further stabilized by additional tertiary base pairs 
between conserved nucleotides of the D-loop and of the V-loop. While conservation of nucleotides at given positions of the present-day tRNAs results from long coevolution of tRNA population with all elements of translation machinery $[7,8]$, the enzymes that produce identical modified nucleotides are often distinct from one organism to another. This is particularly true when considering organisms belonging to different Domains of Life, attesting for convergent type of enzyme evolution for maintaining a universal functional tertiary tRNA fold.

\section{The Intricate T-D-Loop Anatomy}

Figure 1A displays the nearly universal secondary structure of mature tRNA sequences in which the conserved and semiconserved nucleotides present in both the T-loop and the D-loop are highlighted. In the T-loop, those nucleotides which are usually posttranscriptionally modified are indicated in red (Figure 1A,B and Figure 2). Their presence is dependent on both the type of isoacceptor tRNA and the group of organisms considered (Bacteria, Eukarya, and Archaea) (Figure 1C). In the D-loop, only 2'-O-ribose methylated G at position $18(\mathrm{Gm})$ is mentioned among others not discussed here. The case of initiator tRNA of Eukarya is special because an A instead of the universally conserved $\mathrm{U}$ is found at position 54 of T-loop $[9,10]$.

A

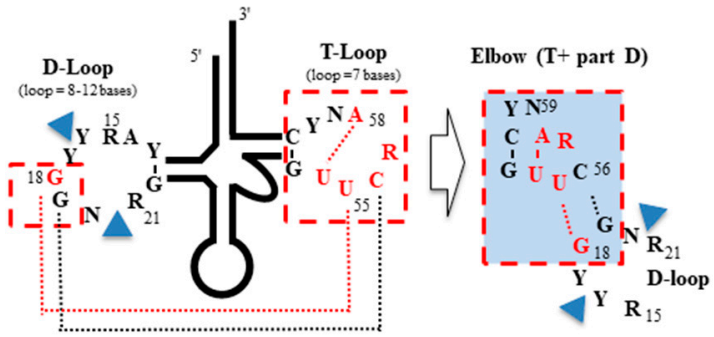

B

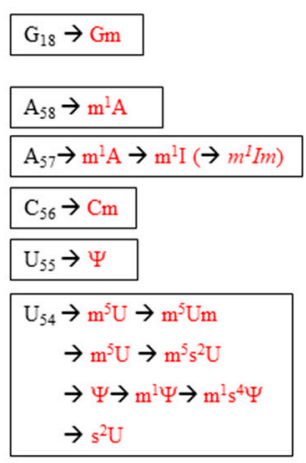

$\mathrm{C}$

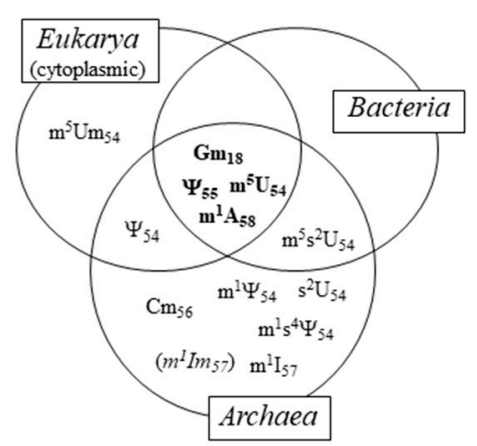

Figure 1. Presence of modified nucleotides in the tRNA elbow structure. (A) Two-dimensional representation of tRNA emphasizing conserved residues involved in D-and T-loop interaction. In red are the residues subject to enzymatic modifications. The little blue box on the right corresponds to the one in Figure 3 (see text for explanation). R stands for purine, $\mathrm{Y}$ for pyrimidine, and $\mathrm{N}$ for any of the four canonical nucleotides. (B) Residues at G18 and in the T-loop and their observed modifications are shown in red. (C) Distribution of modified residues of the T-loop among organisms of the three Domains of Life. Acronyms for modified nucleotides are those used in Modomics [10]. The $2^{\prime}$-O-methylation of $\mathrm{m}^{1} \mathrm{I} 57$ into $\mathrm{m}^{1} \mathrm{Im} 57$ is putative (see text).

X-ray diffraction data of several tRNAs reveal the presence of a trans Watson-Crick/Ho ogsteen pair between the uridine-54 and the adenosine-58 (both in anti-conformation) [11-13]. In the case of eukaryotic $\mathrm{tRNA}_{\mathrm{i}}{ }^{\text {Met }}$, a longer purine-purine Hoogsteen pair (A54-A58) is found [14]. This conserved U54 (A54)-A58 base-pair stacks with the conserved G53-C61 base-pair at the end of the helical T-arm. This forces the conserved pyrimidine-60 (notified as $\mathrm{Y}$ ) and nucleotide-59 (notified as $\mathrm{N}$ for any type of base, but mostly A or $\mathrm{U}$ ) to flip out 
of the remaining 3-member mini-T-loop composed of (i) the conserved U55, which stacks with U54 and interacts with G18 of the D-loop, (ii) C56, which pairs with G19, and (iii) purine-57 (notified as R; mostly G in Bacteria and Eukarya but A in Archaea). The residue R57 is sandwiched between A58-U54 and G19-C56. Thus, the series of nucleotides C61, A58, G18, R57, and C56-G19 are forming a continuous stack (see right part of Figures 1A and 3). The flipped dinucleotide, located between the T- and the D-domain is further stabilized out of the rest of T-loop by an H-bond between the $5^{\prime}$-phosphate of pyrimidine 60 and $\mathrm{N}^{4}$ of C61. This explains the strict conservation of the G53-C61 base pair at the end of the T-stem. In this intricate network of interacting nucleotides, key contacts are the U54-A58 Hoogsteen pair (highlighted in red in Figure 3) and the base pairs formed between the conserved U55 and C56 of the T-loop and the conserved G18 and G19 of the D-loop (highlighted in black in Figure 3). The region where the D-loop and the T-loop interact is designated as the tRNA elbow [15]. The final functional L-shaped conformation is further stabilized by a few additional tertiary base pairs between other conserved or semiconserved nucleotides of the D-loop and V-loop, such as the conserved so-called Levitt base-pair R15-Y48 [15,16] and the conserved triple interacting bases R21-A14-U8 [2,17]. Microstructural heterogeneities in the hinge part of the 3D-core results mostly from the variable number of additional bases present in the D-loop (often dihydrouridine) and V-loop of the different isoacceptor tRNAs (indicated by small blue triangles in Figure 1A). This variability in the hinge region allows some tRNA flexibility but does not alter much the global canonical L-shaped tRNA architecture that is mostly dominated by the T-D-loop kissing-type of complex (elbow).

\section{U modifications}

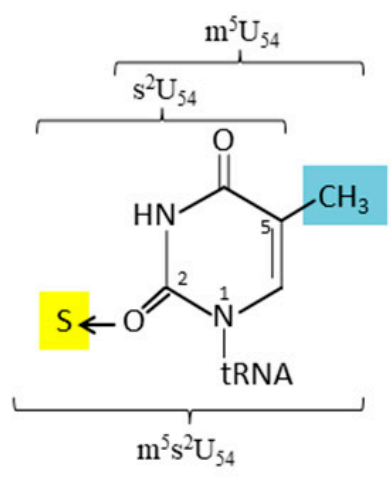

A modifications

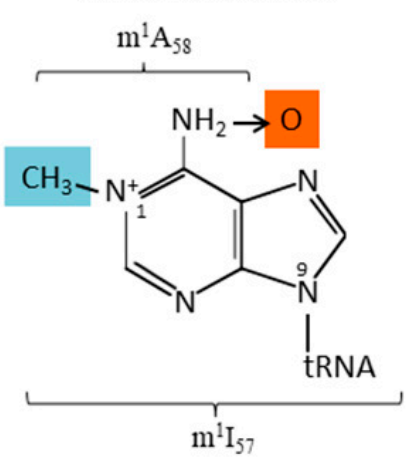

$\Psi$ modifications

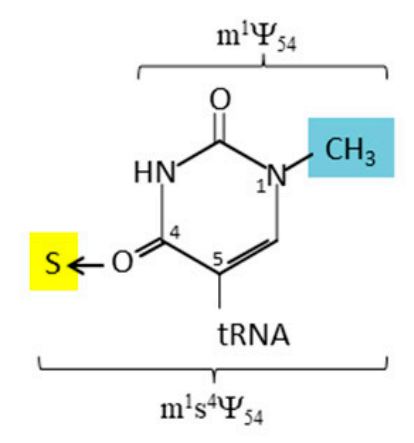

Ribose modification

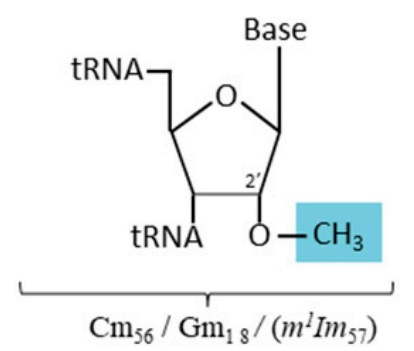

Figure 2. Chemical structure of the modified nucleotides found in the T-loop and G18. 


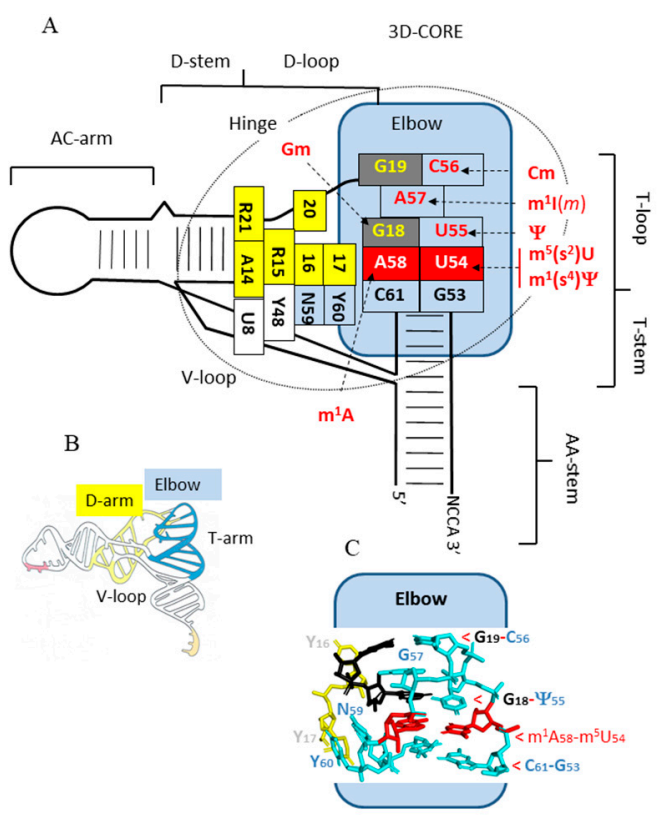

Figure 3. Scheme recapitulating the organization of the elbow within the general 3D organization of tRNA. (A) Rectangles correspond to nucleotides involved in stacking or base-pairing with another nucleotide of the T- and D-loop. Residues involved in the trans Watson-Crick/Hoogsteen interaction are in red boxes, other residues of the T-loop are in blue boxes, while those of the D-loop are in yellow boxes, except G18 and G19 in black boxes. The possible modifications of each residue are indicated in red. (B) Schematic representation of the 3D architecture of tRNA molecule. (C) The 3D structure of tRNA elbow as found in the crystal structure at $1.93 \AA$ resolution of yeast $\mathrm{tRNA}^{\text {Phe }}$ harboring $\mathrm{m}^{5} \mathrm{U} 54$, $\Psi 55$, and $\mathrm{m}^{1} \mathrm{~A} 58$ [13]. The trans Watson-Crick/Hoogsteen interaction is in red, while G18 and G19 are in black.

\section{Modified Nucleotides within the T-Loop and G18 Stabilize the Elbow of tRNA}

The chemical structures of the various modified nucleotides found in the T-loop are depicted in Figure 2. Isomerization of U55 into the universally conserved $\Psi 55$ favors the $3^{\prime}$-endo sugar pucker as in the A-form of RNA and enhances the stacking interaction with the trans Watson-Crick/Hoogsteen pair U54-A58 and the nearest-neighbor purine 57 [18]. The additional H-bound at $\mathrm{N}^{1}$ of $\Psi 55$ involves the $5^{\prime}$-adjacent phosphate via a coordinated water molecule [19]. Likewise, methylation of the $\mathrm{C}^{5}$ atom of U54 into $\mathrm{m}^{5} \mathrm{U}$ and isomerization of U54 into $\Psi 54$ followed by the $\mathrm{N}^{1}$-methylation of $\Psi 54$ similarly favors the $3^{\prime}$-endo ribose puckering of the modified nucleotides and reinforces the hydrophobicity of the base. This increases base stacking with the neighboring bases G53 and $\Psi 55$. Methyl groups also increase steric hindrance, block hydrogen bonds at Watson-Crick positions, and increase resistance against hydrolysis by nucleases. In thermophilic Bacteria and Archaea (growing at temperatures above $60^{\circ} \mathrm{C}$ ), the uridine-54 is almost invariably hypermodified into thiolated derivatives $\left(\mathrm{m}^{5} \mathrm{~s}^{2} \mathrm{U}\right.$ or $\left.\mathrm{m}^{1} \mathrm{~s}^{4} \Psi\right)[20,21]$. Remarkably, hypermodified $\mathrm{m}^{5} \mathrm{~s}^{2} \mathrm{U}$ and $\mathrm{m}^{1} \mathrm{~s}^{4} \Psi$ at position 54 are isosteric, which implies that in both cases, the bulky highly polarizable thio group reinforces the $3^{\prime}$-endo ribose puckering of the nucleotide. This considerably enhances the stacking interaction with the nearest-neighboring nucleotides G53 and $\Psi 55$ [22] and allows base pairing in an identical way with the trans-Hoogsteen nucleotide 58 .

Methylation of the $2^{\prime}$-hydroxyl of the ribose favors the $3^{\prime}$-endo-conformation and changes the hydration sphere around the oxygen of the ribose [23]. Further, $2^{\prime}$-O-ribose methylation of cytidine at position $56(\mathrm{Cm})$ was found in tRNAs of the crenarchaeon Pyrobaculum aerophilum [24] and also of $\mathrm{N}^{1}$-methyl-inosine at position $57\left(\mathrm{~m}^{1} \mathrm{Im}\right)$ in $\mathrm{tRNAs}$ of Pyrobaculum islandicum and of Pyrodictium occultum. However, in this latter case information comes from analysis of bulk tRNA with no evidence for the presence of $\mathrm{m}^{1} \mathrm{Im}$ at position 
57 exclusively [25]. $2^{\prime}$-O-ribose methylation of $\mathrm{m}^{5} \mathrm{U}$ at position $54\left(\mathrm{~m}^{5} \mathrm{Um}\right)$ exists in certain tRNAs of Eukarya [26]. Residue Gm18 in the D-loop is found in tRNAs of all Domains of Life but are more frequently found in thermophilic Bacteria and hyperthermophilic Archaea [20]. This methylation is diagonally opposite to the 2'-O-methylation of C56 (Cm) that base pairs with the conserved neighboring G19.

Methylation of the $\mathrm{N}^{1}$ atom of adenosine 58 blocks a Watson-Crick position and favors the formation of an intraloop Watson-Crick/Hoogsteen pairing with $\mathrm{m}^{5} \mathrm{U} 54$ or $\Psi / \mathrm{m}^{1} \Psi 54$. The electropositive character of this methylated adenosine also promotes ionic interaction with the negatively neighboring charged phosphates of the backbone. In Bacteria and Eukarya, the conserved purine 57 is more often G57 than A57, while in thermophilic and hyperthermophilic Archaea, a neutral $\mathrm{N}^{1}$-methylinosine $\left(\mathrm{m}^{1} \mathrm{I}\right)$ is often found instead. Such deaminated adenosine can establish $\mathrm{H}$-bonds as a guanosine. Nucleotide in position 57 (G57 or derivatives of A57) is sandwiched between the base pairs G18-U55 and G19-C56 of the tRNA elbow (Figure 3). Notice, the presence of $\mathrm{m}^{1} \mathrm{~A} 58$ and/or $\mathrm{m}^{1} \mathrm{I} 57$ depends much on the archaeon considered and the type of tRNA analyzed (especially the nature of nucleotide-59, see below). For example, most tRNAs from halophilic Archaea such as Haloferax volcanii display $\mathrm{m}^{1} \mathrm{I} 57$ and unmodified A58 [27,28], while tRNAs of thermophilic and hyperthermophilic Archaea often display m ${ }^{1}$ A58 and /or m ${ }^{1}$ I57 [29] and references therein.

In sum, the highly conserved nucleotide modifications of the T-loop and of G18 of the D-loop mainly serve to enhance the intrinsic stability of the tRNA elbow and also to enhance the affinity between the T- and D-loop, especially in the thermophilic organisms [30].

\section{The Enzymatic Toolbox for Nucleotide Modifications at Positions 18 (D-Loop) and 54-58 (T-Loop) of tRNA}

The elbow region of tRNAs of Bacteria and Eukarya contains characteristic conserved noncanonical nucleotides at positions 18, 54, 55, and 58, while in Archaea, additional conserved modifications also occur at positions 56 and 57 (Figures 1 and 2). They are all catalyzed by specific enzymes during the tRNA maturation process (Figures 4 and 5).

\subsection{G18 Modification in the D-Loop}

In tRNA species of most Gram-negative Bacteria the highly conserved guanosine-18 is converted to a 2'-O-methylated derivative (Gm). Gm18 is absent in Gram-positive Bacteria with a few exceptions such as the thermophilic Geobacillus sp (reviewed in [31]). This modification is accomplished by the dimeric S-adenosyl-L-methionine (SAM)-dependent methyltransferase (MTase) TrmH belonging to the SPOUT superfamily [32] (COG0566Cluster of Orthologous Genes, see [33]). Two types of TrmH enzymes exist with different tRNA recognition specificities: one methylating all tRNA types, like TrmH of Thermus thermophilus, and the other one methylating only a specific subset of tRNAs like TrmH of Escherichia coli and Aquifex aeolicus [34-36], reviewed in [37].

In yeast, Gm18 formation is catalyzed by the dimeric TRM3 MTase also belonging to the SPOUT superfamily (COG0566). Yeast TRM3 exhibits a very long N-terminal extension of unknown function [38]. The human homologous enzyme is TARBP1 [39].

In Archaea, while Gm18 has been experimentally identified in tRNA of different thermophilic organisms [29], no stand-alone homolog of TrmH/TRM3 has yet been identified. Instead, an alternative pathway involving a $\mathrm{C} / \mathrm{D}$ box guide has been suggested, as in the case of 2'-O-ribose methylation of C56 of the T-loop (see below) and also for other nucleotides in the anticodon loop and position 50 of the T-arm [40,41]. Methylation will then occur via a nucleoprotein complex involving the ad hoc C/D box guide RNA, two protein cofactors Nop5 and L7Ae, and a SAM-dependent fibrillarin-like MTase (FlpA, belonging to COG1889). 


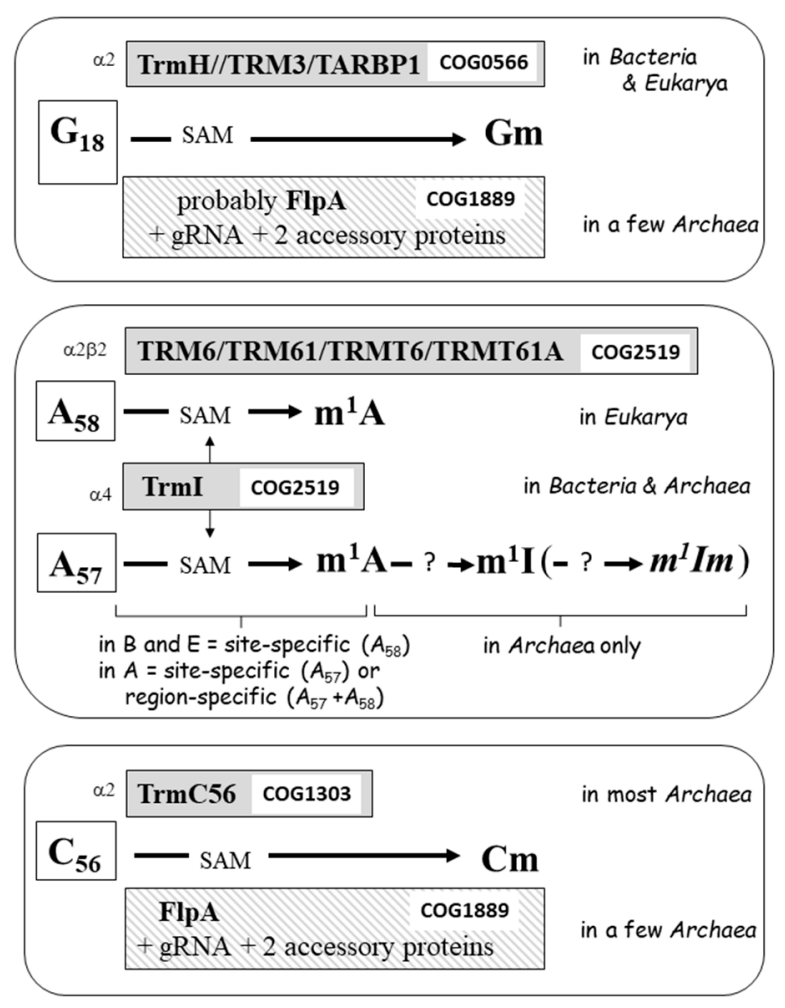

Figure 4. Enzymatic systems involved in post-transcriptional modifications of selected nucleotides of the D-and T-loop of tRNAs of various organisms. Acronyms of enzymes are boxed with various backgrounds according to the type of modification together with the COG (Cluster of Orthologous Genes) number. The Greek symbols indicate the oligomerization state of the functional enzymes. Only in a few cases, the enzyme corresponding to a given modification remains unknown (indicated by?). The $2^{\prime}-O$-methylation of $\mathrm{m}^{1} \mathrm{I} 57$ into $\mathrm{m}^{1} \mathrm{Im} 57$ is putative (see text). Acronyms for modification enzymes are those used in Modomics [10], except for those in human [39]. gRNA stands for guide RNA. A, B, and E refer, respectively, to Archaea, Bacteria, and Eukarya.

\subsection{Modification of $A 58$ and $A 57$}

$\mathrm{N}^{1}$-methyladenosine $\left(\mathrm{m}^{1} \mathrm{~A}\right)$ is often present at position 58 of tRNAs of organisms belonging to all three Domains of Life. Its formation, role, and structural implications has been the subject of various reviews [42-46].

In Bacteria, like T. thermophilus, for which $\mathrm{m}^{1} \mathrm{~A} 58$ is present in all sequenced tRNAs, the enzyme catalyzing this $\mathrm{N}^{1}$-adenine methylation is the homotetrameric $\operatorname{TrmI}[47,48]$. This SAM-dependent enzyme belongs to the Rossman fold-like (RFM/class I) family of MTases (COG2519) and is site-specific for the $\mathrm{N}^{1}$-position of A58 [47]. The T-loop in combination with the aminoacyl-stem and the variable region are required for efficient methyl transfer [49].

In Eukarya, like yeast and human, a site-specific A58 TrmI-like ortholog exists but displays a different protein architecture. Here, the enzyme is a heterotetramer composed of two different kinds of subunits: a catalytic SAM-binding protein (TRM6/TRMT6 belonging to RFM/class I) and an evolutionary related RNA binding protein (TRM61/TRMT61A), both belonging to COG2519. As for bacterial TrmI, eukaryal $\mathrm{N}^{1}$-adenine MTase is sitespecific for A58 and requires the T-loop in combination with the aminoacyl-stem [50-53], reviewed in [54].

In hyperthermophilic Archaea, like Pyrococcus furiosus or Pyrococcus abyssi, the TrmI ortholog works as a homotetramer. However, at variance with the bacterial enzyme, it involves intersubunit disulfide bridges that reinforce the tetrameric oligomerization [55,56]. This archaeal TrmI can work in vitro on a minisubstrate composed of only the T-branch [50]. Remarkably, it methylates the $\mathrm{N}^{1}$-atom of both neighboring adenosines 58 and 57 of the 
T-loop, with a preference for position A57. This region specificity depends on the presence of an adenosine at position 59 of tRNA. In absence of A59, archaeal TrmI behaves as an A57-specific MTase [57]. A model based on fluorescence measurements of 2-aminopurine placed at positions 57 or 58 , showed that methylation is sequential, forming $\mathrm{m}^{1} \mathrm{~A} 57$ before $\mathrm{m}^{1} \mathrm{~A} 58$ [58]. In archaeal tRNAs, $\mathrm{m}^{1} \mathrm{~A} 57$ never accumulates, i.e., the 6-amino group of adenine is always very efficiently deaminated by a new type of hydrolytic deaminase (still to be identified) leading to formation of 1-methylinosine ( $\left.\mathrm{m}^{1} \mathrm{I} 57\right)[59,60]$. The nucleotide 57 is sandwiched between G19-C56 and G18-U55 (see above). The still unknown $\mathrm{m}^{1} \mathrm{~A}$ dependent deaminase removes the positive electrostatic charge of the $\mathrm{N}^{1}$-atom of $\mathrm{m}^{1} \mathrm{~A}$ (Figure 2), leading to the neutral $\mathrm{m}^{1} \mathrm{I}$ residue. Although it is difficult to evaluate the molecular effects of the latter modification, it is conceivable that $\mathrm{m}^{1}$ I stabilizes stacking interactions better than $\mathrm{m}^{1} \mathrm{~A}$. On the contrary, the presence of a positively charged $\mathrm{m}^{1} \mathrm{~A} 58$ has been demonstrated to be critical for the folding of the T-loop and proper functioning of certain tRNAs (discussed in [61,62]). In the majority of other bacterial and eukaryal tRNAs, nucleotide 57 is usually $\mathrm{G}$ or unmodified A. As for $\mathrm{N}^{6}$-methyladenosine $\left(\mathrm{m}^{6} \mathrm{~A}\right)$ in mRNA, $\mathrm{m}^{1} \mathrm{~A}$ in human tRNAs has been found to be occasionally demethylated by a specific enzyme [63], reviewed in [64].

\subsection{Modification of $\mathrm{C} 56$}

The presence of 2'-O-methylcytidine $(\mathrm{Cm})$ at position 56 is a hallmark of archaeal tRNAs. It has never been found in any tRNA of Bacteria nor of Eukarya. As for the formation of Gm18 (see above), two different evolutionary unrelated enzymatic mechanisms exist to catalyze this ribose methylation. In most Archaea, $\mathrm{Cm} 56$ formation is achieved by the stand-alone SAM-dependent Trm56 belonging to COG1303 [65]. Little is known about tRNA recognition by this enzyme. Nevertheless it seems that besides the C56, the enzyme recognizes more than just the T-stem-loop, at least in vitro and with unmodified tRNA transcripts as substrates $[65,66]$. This dimeric MTase belongs to the same SPOUT superfamily as the G18-MTase (TrmH/TRM3/TARBP1) but belongs to a different COG [37,67]. In other Archaea, such as the hyperthermophilic Pyrobaculum aerophilum, Cm56 formation is achieved by a nucleoprotein complex composed of a fibrillarin-like MTase (FlpA, COG1889), two protein cofactors (Nop5 and L7Ae) and a specific small C/D guide RNA that allows the FlpA enzyme to find its target nucleotide [65], reviewed in [24]. This enzymatic pathway is the same as the one catalyzing formation of $\mathrm{Gm} 18$, except that distinct guide RNAs are used. Interestingly, a simplified heterodimer composed of $P$. abyssi FlpA and Nop5 can perform SAM-dependent 2'-O-methylation of RNA in vitro independently of L7Ae and $\mathrm{C} / \mathrm{D}$ guide RNA. This stand-alone activity of dimeric FlpA-Nop5 may reflect the ancestral activity of the enzyme, before its recruitment into larger complexes [68].

\subsection{Modification of $U 55$}

Pseudouridine ( $\Psi)$ at position 55 is the most universally conserved modified nucleotide in tRNA of all three phylogenetic Domains of Life. Nevertheless, as for several other modified nucleotides discussed in this work, different enzymatic strategies are used to catalyze this simple isomerization reaction in different organisms.

In Bacteria and Eukarya, stand-alone $\Psi 55$-synthase TruB (in E. coli) and its ortholog PUS4/TRUB1 (in Saccharomyces cerevisiae/human) catalyze this modification [69-71]. These monomeric enzymes belong to COG0130, which also includes the close homolog Cbf5 (see below). Bacterial TruB in complex with its RNA substrate is probably the best characterized system involving a modification enzyme [72-75]. This bacterial TruB enzyme, as well as its eukaryal orthologs PUS4/TRUB1 require no cofactors and accept as substrate a simple 17 base oligonucleotide analog to the T-arm and containing the sequence 53-GUUYRANYC$61[70,76]$. This explains why these enzymes efficiently work on unmodified precursor tRNAs (including synthetic molecules) and on many cellular RNAs (other than tRNAs) in vitro and in vivo, as long as the target position in the RNA substrate remains accessible to the enzyme. Besides its catalytic function, bacterial TruB also acts as RNA chaperone [77]. 
In Eukarya and Archaea, but not in Bacteria, two additional enzymes are implicated in $\Psi 55$ formation. The first usually functions in a ribonucleoprotein complex that utilizes a well-structured box H/ACA guide RNA to target the sequence to be modified, two or three protein cofactors (Nop10, Gar1, and Nhp2 in Eukarya and Nop10, Gar1, and L7Ae in Archaea) and the enzyme Cbf5 belonging to the same COG0130 as PUS4/TRUB1. In Eukarya, such H/ACA guided enzymatic system is used essentially for site-specific catalysis of $\Psi$ formation in various cellular RNA targets, mostly rRNA, and not tRNA (reviewed in [78-80]). In Archaea, Cbf5 can function as a stand-alone $\Psi$-synthase for tRNA $\Psi 55$ formation, at least in vitro [81-84]. This guide-independent tRNA specific activity of archaeal $\mathrm{Cbf} 5$ is enhanced in vitro by the proteins Nop10 and Gar1, probably by stabilizing the active conformation of $\mathrm{Cbf5}$ [82,85-87]. It is worth mentioning that the Haloferax volcanii cbf5 deletion strain still contains tRNA carrying $\Psi 55$, attesting that Cbf5 is not the main physiological $\Psi 55$ synthase, at least in this archaeon [88]. This is another example of the probable ancestral activity retained in the present-day $\mathrm{Cbf} 5$ enzyme that was recruited into larger complexes later during evolution.

In Archaea, the genuine enzyme catalyzing $\Psi 55$ formation in tRNA is the standalone Pus10 belonging to COG1258, phylogenetically unrelated to TruB/PUS4/TRUB1 (COG0130) [81,83]. This monomeric $\Psi$-synthase needs no protein cofactors and is present in a large variety of Archaea (mostly in Euryarchaeota and a few Crenarchaeota). It is also present in a few Eukarya (including human) but not in Bacteria [89,90]. In archaeal tRNAs the main target is U55, but depending on the archaeon considered, Pus10 behaves as a region-specific enzyme catalyzing $\Psi$ formation at both positions 55 and 54 (see below).

In human, the situation is more complicated due to the coexistence of nuclear/cytoplas mic 455 -specific TRUB1 and of mitochondrial TRUB2 (not discussed here). While recombinant human PUS10 can generate $\Psi 55$ in human cytoplasmic tRNAs in vitro [91], its main cellular function is to promote pseudouridylation of U54 in only a small subset of the total cytoplasmic tRNA population (see below), the formation of $\Psi 55$ in the majority of the other human tRNAs being achieved in the nucleus by TRUB1.

\subsection{Modification of U54}

Methylation of the $\mathrm{C}^{5}$-atom of uridine at position $54\left(\mathrm{~m}^{5} \mathrm{U}\right.$, also referred as ribothymidine rT), is the second most commonly found modified nucleotide in tRNAs of Bacteria and Eukarya. In Archaea, it is only found in a small subset of organisms belonging to Thermococcales and the sister lineage Nanoarchaeota.

In E. coli, $\mathrm{m}^{5} \mathrm{U} 54$ formation is catalyzed by the monomeric SAM-dependent TrmA enzyme of the RFM superfamily belonging to GOG2265 [92]. Its presence, but not its enzymatic activity is essential for $E$. coli viability $[93,94]$. This is probably explained by the chaperone activity of TrmA during tRNA maturation [95]. In yeast, the orthologous enzyme is TRM2 and in human TRMT2A [96,97].

In Bacteria, the use of SAM as a methyl donor by the TrmA enzyme is common for $\mathrm{m}^{5} \mathrm{U} 54$ formation in $\beta$ - $\gamma$-and $\varepsilon$-Proteobacteria, while in Firmicutes, $\alpha$-and $\delta$-Proteobacteria as well as in Cyanobacteria and Deinococci, the enzyme responsible for the methylation of U54 is the flavoprotein TrmFO. This enzyme uses $\mathrm{N}^{5}, \mathrm{~N}^{10}$-methylenetetrahydrofolate $\left(\mathrm{CH}_{2}=\mathrm{THF}\right)$ in a more complex mechanism than the rather simple methyl transfer from SAM. Here, a methylene group is transferred first and a subsequent reduction step involving the flavin adenine dinucleotide hydroquinone $\left(\mathrm{FADH}^{-}\right)$is required to form the final methylated derivative [98,99], reviewed in [100]. The monomeric folate/FAD-dependent TrmFO enzyme belongs to COG1206. In Mollicutes, a group derived from Firmicutes and displaying extensive genome erosion (retrograde evolution), several SAM-dependent $\mathrm{m}^{5} \mathrm{U}$ MTases present in their common ancestor have been lost and replaced by folate-dependent paralogs [101,102]. These are clear examples of independent and mutually exclusive evolution of analogous enzymes catalyzing the formation of the same modification ( $\left.\mathrm{m}^{5} \mathrm{U} 54\right)$ using totally unrelated mechanisms in different bacterial lineages. 


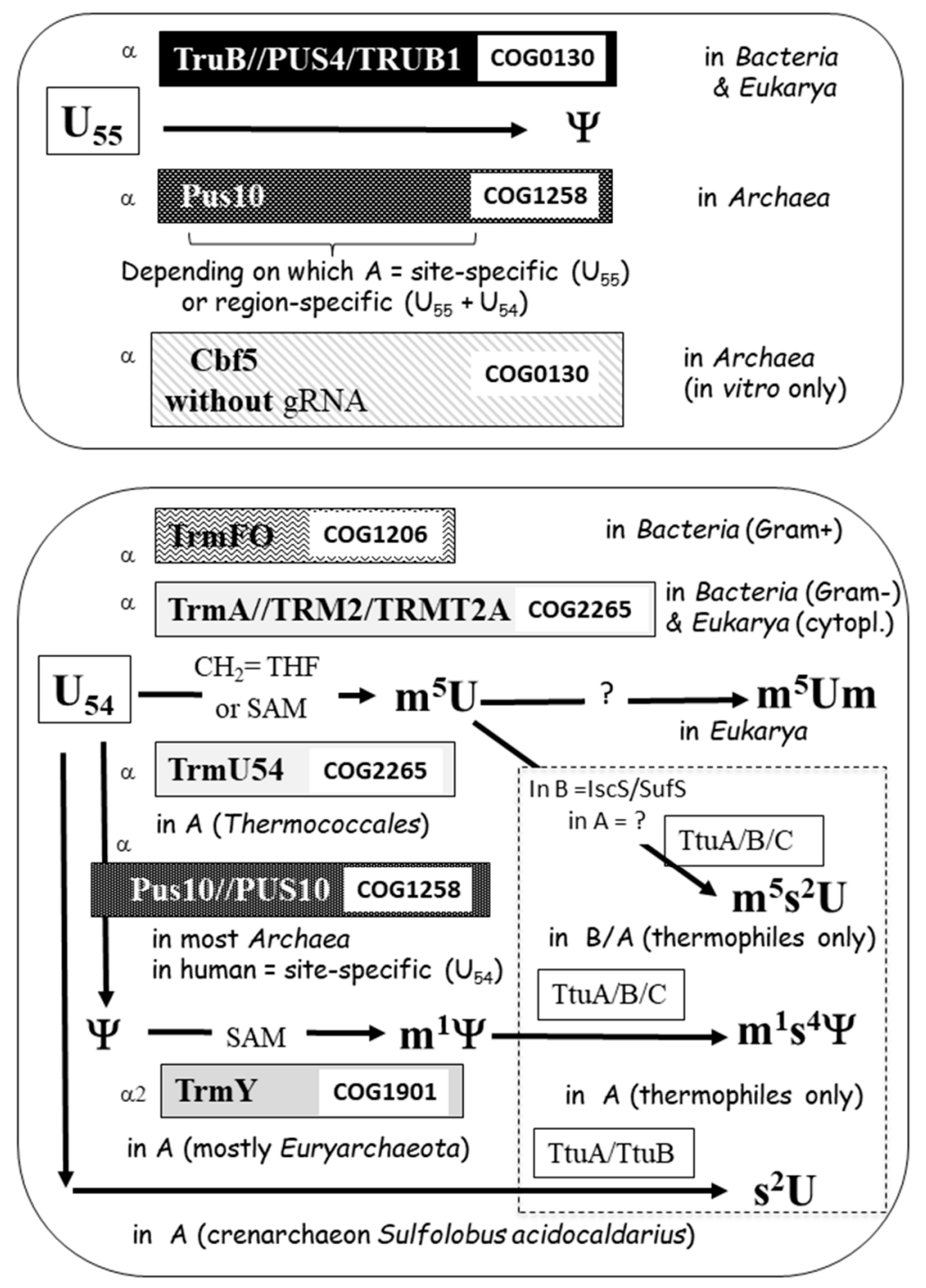

Figure 5. Enzymatic systems involved in post-transcriptional modifications of U55 and U54. Same as legend to Figure 4.

In the hyperthermophilic Archaea of the phyla Thermococci (such as $P$. abyssi and $P$. furiosus) and Nanoarchaeota (as Nanoarchaeum equitans), $\mathrm{m}^{5} \mathrm{U} 54$ formation is catalyzed by TrmU54, a SAM-dependent MTase belonging to COG2265. Although this monomeric protein belongs to the same COG as TrmA/TRM2/TRMT2A, the protein sequence of archaeal TrmU54, as well as eukaryal TRM2, are more similar to the bacterial paralog RImD (formerly, RumA/RumT) catalyzing $\mathrm{m}^{5} \mathrm{U} 1939$ formation in 23S rRNA [103]. One main difference is the presence of an iron-sulfur cluster in the archaeal TrmU54 [104]. In both cases, these two enzymes, TrmU54 and TRM2, arose from an ancestral horizontal transfer (endosymbiosis in the case of TRM2) followed by a shift of function from rRNA to tRNA modification [103,105].

All these MTases are site-specific and methylate exclusively the $C^{5}$-atom of U54. As for TruB/PUS4 above, the minimal RNA structure for substrate recognition by TrmA, TRM2, and TrmU54 is a 5-base-pair stem, eventually prolonged with the amino acid arm, and a seven-membered loop as in a canonical T-loop of tRNA [50,66,70,75,106-108]. The same applies to tRNA recognition by bacterial TrmFO [109].

Depending on the organism, residue $\mathrm{m}^{5} \mathrm{U} 54$ can be further modified by either $2^{\prime}-\mathrm{O}-$ methylation or thiolation. In rabbit and human, $2^{\prime}-O$-methylated derivative of $\mathrm{m}^{5} \mathrm{U} 54$ $\left(\mathrm{m}^{5} \mathrm{Um}\right)$ was reported for $\mathrm{tRNA}^{\mathrm{Lys} 3}[26,110]$. The corresponding MTase remains to be identified. In both thermophilic Bacteria and Archaea, $\mathrm{m}^{5} \mathrm{U} 54$ is further modified in $\mathrm{m}^{5} \mathrm{~s}^{2} \mathrm{U} 54$ 
by a thiolation enzymatic machinery involving several proteins (TtuA, TtuB, TtuC, and cysteine desulfurases IscS or SufS in Bacteria, not yet known in Archaea) [111], reviewed in [112]. In T. thermophilus, the level of thiolation enzyme and, consequently, the degree of tRNA $\mathrm{m}^{5} \mathrm{U}$ thiolation increases with increasing cultivation temperatures [113]. The major determinants for 2-thiolation of $\mathrm{m}^{5} \mathrm{U} 54$ is the presence of the conserved C56 and $\mathrm{m}^{1} \mathrm{~A} 58$ of the T-loop. Tertiary interactions between the T- and D-loops and nonconserved nucleotides in the T-loop are not important for the reaction [114]. The importance of $\mathrm{m}^{1} \mathrm{~A} 58$ for $\mathrm{m}^{5} \mathrm{~s}^{2} \mathrm{U} 54$ formation is supported by the fact that a $\Delta \mathrm{trmI}$ strain of T. thermophilus loses its ability to grow at higher temperature range [47,113], reviewed in [20]. Moreover, the presence of $\mathrm{m}^{7} \mathrm{G} 46$ in the V-loop allows a better efficient thiolation reaction attesting for a clear interplay between the different modifications in tRNA [115].

In Archaea, other than Thermococci and Nanoarchaeota, and a few Eukarya, U54 is modified to $\Psi$. This isomerization reaction is catalyzed by the $\Psi$-synthase Pus10/PUS10 already mentioned above for catalyzing $\Psi 55$ formation. However, depending on the archaeon, Pus10 can be either site-specific for U54 or region-specific for both U55 and U54. When tested in vitro, recombinant Pus10 of Methanocaldococcus jannaschii catalyzes formation of both $\Psi 55$ and $\Psi 54$ with the same efficiency, whereas recombinant Pus 10 of $P$. furiosus is inefficient for catalyzing $\Psi 54$ formation under the same experimental conditions [83]. When tested in vivo, recombinant $M$. jannaschii Pus10 also efficiently forms both $\Psi 55$ and $\Psi 54$ in tRNAs of a double (truB-trmA)-mutant E. coli strain. In contrast, recombinant $P$. furiosus Pus 10 only forms $\Psi 55$ in the same tRNAs of the E. coli doublemutant strain [116]. Such versatility of archaeal Pus10 is consistent with the fact that in naturally occurring tRNAs of $P$. furiosus an $\mathrm{m}^{5} \mathrm{U} 54$ is present, while in M. jannaschii, tRNAs $\mathrm{m}^{1} \Psi 54$ is found. Thus, the restricted specificity of P. furiosus Pus10 for U55 avoids a competition with methylation of U54 by TrmA [83]. Recombinant human PUS10 can also catalyze $\Psi 55$ and $\Psi 54$ formation in vitro [117], attesting for adaptation of the enzyme specificity according to the cellular need [116]. Maximal $\Psi 54$ synthase activity is observed for tRNA substrates with the sequence 53-GUUCAm ${ }^{1}$ AAUC-61 along with a stable acceptor stem. As for the archaeal Pus10, the crystal structure of human PUS10 shows the presence of a conserved $\Psi$-synthase catalytic domain fused to a characteristic THUMP domain [118]. THUMP is an RNA-binding module that is also present in a few other tRNA modification enzymes such as thiouridine synthases and MTases [119-124].

In Archaea (mostly Euryarchaeota but also in a few Crenarchaeota), $\Psi 54$ can be further methylated into $\mathrm{m}^{1} \Psi 54$ by a SAM-dependent MTase (TrmY) belonging to COG1901 [125,126]. The structure of this dimeric enzyme shows that it belongs to the SPOUT superfamily [127]. In Vitro experiments with purified recombinant region-specific M. jannaschii Pus10 and TrmY demonstrates that TrmY (as Pus10 above) can produce $\mathrm{m}^{1} \Psi$ in a 17-base fragment of a tRNA transcript corresponding to the T-arm of which U55 (possibly $\Psi 55$ ) cannot be mutated [125]. In thermophilic Archaea, residue $\mathrm{m}^{1} \Psi 54$ can be further thiolated to $\mathrm{m}^{1} \mathrm{~s}^{4} \Psi 54$ most probably by the same thiolation enzymatic machinery reported above for $\mathrm{m}^{5} \mathrm{~s}^{2} \mathrm{U} 54$ formation in thermophilic Bacteria (involving proteins TtuA, TtuB, TtuC, and cysteine desulfurases not yet identified in Archaea). For example, in tRNAs of Ignicoccus hospitalis, a member of the Crenarchaeota, $\mathrm{m}^{1} \mathrm{~s}^{4} \Psi 54$, is found, whereas in tRNAs of Nanoarchaeum equitans, closely related to the Thermococcales, $\mathrm{m}^{5} \mathrm{~s}^{2} \mathrm{U} 54$ is present [21]. These two Archaea are growing physically attached as obligate partners exchanging various metabolites under hyperthermophilic conditions [128]. Remarkably, the methyl and thio groups in $\mathrm{m}^{1} \mathrm{~s}^{4} \Psi$ and $\mathrm{m}^{5} \mathrm{~s}^{2} \mathrm{U}$ are presented in the same spatial manner for the stabilization of the $3^{\prime}$ endo-anti conformation of nucleotide 54, showing that these Archaea use different but structurally equivalent modifications to stabilize their T-loops. This illustrates how different solutions have been adopted during evolution to fulfil the same function.

Finally, in the case of the hyperthermophilic crenarchaeon Sulfolobus acidocaldarius, $s^{2} \mathrm{U}$ has been found at position 54 of several tRNAs. In the particular case of tRNA ${ }^{\mathrm{Val}}$, a methylthio U-derivative was also found, but its chemical structure remains elusive [29]. Examination of the $S$. acidocaldarius genome reveals the presence of genes coding for TtuA 
and TtuB responsible for thiolation of U54 but no gene coding for $\operatorname{TrmA}$ (catalyzing $\mathrm{m}^{5} \mathrm{U} 54$ ), Pus10 (catalyzing $\Psi 54$ in addition of $\Psi 55$ ), and TrmY (catalyzing $\left.\mathrm{m}^{1} \Psi 54\right)$ was found. One possibility is that ribose methylation of U54 occurs in only a few tRNA species, such as the initiator tRNA [129]. Indeed, 2'-O-methylated nucleotides are found at several positions of various $S$. acidocaldarius tRNAs and are known to be formed by the guide RNA-dependent FlpA machinery $[130,131]$. However, no guide RNA specific for U54 methylation has been reported up to now. Therefore, in absence of a clear-cut evidence for Um54 existence and of convincing information about the corresponding methylation system, this problem remains unsolved.

\section{Temporal Order of Nucleotide Modifications and Their Interdependencies}

After transcription, each tRNA primary transcript (pre-tRNA) is engaged in a complex multistep maturation during which $5^{\prime}$-leader and $3^{\prime}$-trailer are removed, introns are spliced, $5^{\prime}-\mathrm{G}$ (in the case of tRNA ${ }^{\text {His }}$ ) and CCA-end are added (if not encoded in the genome), and a bunch of nucleotides become modified. In Eukarya, this process starts in the nucleus and terminates in the cytoplasm. Along this complex sequential maturation, both the structural conformation and the sequence of the pre-tRNAs are progressively transformed in fully mature and functional tRNA molecules with the canonical L-shaped structure.

During this process, enzymatic modifications introduced by a machinery utilizing guide RNAs that base pair with the pre-tRNA substrate and by enzymes requiring limited small substructures are expected to occur first, while enzymes requiring an intact tRNA architecture are expected to act later. Hence, the earliest expected modifications are Gm18 and $\mathrm{Cm} 56$ (in Archaea), which both depend on guide RNA, and $\Psi 55, \Psi 54, \mathrm{~m}^{5} \mathrm{U}, \mathrm{m}^{1} \Psi 54$, which all depend on stand-alone enzymes working on minimal T-arm substructures. These are precisely the modifications that were experimentally shown to be the first ones to appear during pre-tRNA processing using either in vivo or in vitro assays [50,132-134]. Recently, experiments aiming at monitoring the time-resolved introduction of modifications in yeast

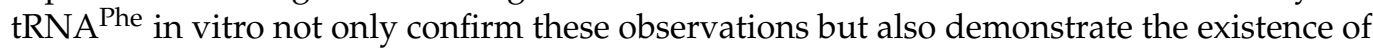
a robust modification circuit (interdependency) starting with the introduction of $\Psi 55$, then $\mathrm{m}^{5} \mathrm{U} 54$, and finally $\mathrm{m}^{1} \mathrm{~A} 58$ [135]. Since the presence of $\mathrm{N}^{1}$-methyl group on A58 is required for efficient enzymatic transfer of sulfur on the $C^{2}$-atom of $\mathrm{m}^{5} \mathrm{U} 54$ [113], the biogenesis of $\mathrm{m}^{5} \mathrm{~s}^{2} \mathrm{U} 54$ by TtuA/TtuB/TtuC at elevated temperature in thermophilic Bacteria and possibly of $\mathrm{m}^{1} \mathrm{~s}^{4} \Psi$ in hyperthermophilic Archaea should occur later during tRNA maturation. These observations are in complete agreement with the theory of interdependency between the various enzymatic modification systems acting on nucleotides in the tRNA elbow, in which $\Psi 55$-synthase TruB/PUS4/TRUB1 (and probably Pus10) appears to be the conductor, besides acting itself as a chaperone protein [136-139]. Interdependency between different nucleotide modifications and their modification pathways has been found to be particularly important for modifications in the anticodon-stem loop [60,140,141].

\section{6. tRNA T-Loop Modification Enzymes Can Modify Other T-Loop Containing RNAs}

Conserved base-pairings between the T-and D-loop are intrinsic properties of the tRNA itself: they are present in synthetic tRNA transcripts lacking any modified nucleotide, yet in slightly more relaxed conformation [142,143]. Genuine T-loop architecture also exists in local regions of the ribosomal RNAs [144], at the $3^{\prime}$ end of the plant viral TYMV RNA [145] and in bacterial tmRNA [146]. In these two last examples, TrmA/TRM2/TRMT2A was shown to catalyze $\mathrm{m}^{5} \mathrm{U}$ formation at the position equivalent to U54 $[147,148]$. The main role of post-transcriptional modifications of the various conserved nucleotides of the T-loop is therefore to fine-tune the dynamics (rigidity/flexibility) of the self-formation of this important part of the tRNA molecule and to facilitate its interaction with the D-loop. As illustrated in Figure 3, the various conserved modified nucleotides $\left(\mathrm{Gm} 18, \mathrm{~m}^{5}\left(\mathrm{~s}^{2}\right) \mathrm{U} / \mathrm{m}^{1} \mathrm{~s}^{4} \Psi 54, \Psi 55, \mathrm{Cm} 56\right.$, and $\left.\mathrm{m}^{1} \mathrm{I} 57 / \mathrm{m}^{1} \mathrm{~A} 58\right)$ are very close together in the L-shaped conformation of tRNA. 


\section{Conclusions and Future Prospects: Unraveling the Evolutionary Origin of tRNA Modification Machinery}

The importance of a few invariant and semi-invariant nucleotides for self-forming 3D-conformation of the T-loop of tRNAs is now well documented. This unique structural domain is characterized by a trans Watson-Crick/Hoogsteen pair between U54 and A58, which, in turn, allows U54, U55, the bulged pyrimidine 60, and nucleotide 59 to further interact specifically with nucleotides of the D-loop (Figure 3) $[149,150]$. Since transcription proceeds in the $5^{\prime}$ to $3^{\prime}$ direction, this T-loop/D-loop interaction cannot take place before almost the full sequence of the tRNA gene is transcribed. In addition, among the many modified nucleotides found in fully matured tRNA molecules, Gm18, $\Psi 55, \mathrm{~m}^{5} \mathrm{U} 54 / \mathrm{m}^{1} \Psi$, $\mathrm{m}^{1} \mathrm{I} 57 / \mathrm{m}^{1} \mathrm{~A} 58$, and $\mathrm{Cm} 56$ are likely the first to occur in the maturation pathway, the most universally conserved $\Psi 55$ being probably the very earliest one. These combinatorial networks of base pairings and nucleotide modifications, together with other tertiary interactions and base modifications within the entire core of the tRNA molecule, permit each individual fully matured isoacceptor tRNA species to adopt a stable still flexible L-shaped conformation [151]. In this final functional conformation, the distance between the anticodon and the CCA- $3^{\prime}$-terminus at the opposite is around $80 \AA$. This property is essential for each aminoacyl-tRNA to accommodate in the decoding center of the small ribosomal subunit and then in the peptidyl-transferase center of the large subunit.

Because of the highly conserved characters of the modified nucleotides found in the T-loop and around G18-G19 among tRNAs of organisms belonging to the three Domains of Life, the simplest ones like $\Psi, \mathrm{Cm}, \mathrm{m}^{5} \mathrm{U}$, and $\mathrm{m}^{1} \mathrm{~A}$ might have been present in the prebiotic soup [152-154]. The corresponding modification enzymes might have appeared later, yet very early in evolution, at least at the root of the common ancestral lineages of Bacteria / Archaea $[155,156]$. If the present-day enzymes would have been vertically inherited from these earliest forms, their sequences should retain substantial similarities among orthologous enzymes present in majority if not all organisms of the Tree of Life. On the contrary, and this is the main message of the present review, almost all the enzymes involved in the modification of nucleotides at positions $18,54,55,56$, and 57/58 differ much from one group of organisms to another, U54 being the most diversely modified one. These nonhomologous enzymes (also named "analogous enzymes" [157]) belong to different COGs, use sometimes different cofactors (such as SAM or CH2 = THF) and mechanisms (standalone or guided-RNA machineries), and recognize different portions of the tRNA molecule. They can be site-, region-, or even dual-specific (for tRNA and other types of RNA). Evidently, emergence and evolution of a given enzymatic activity is more complex than just by gene duplication and neofunctionalization followed by eventual elimination of the ancestral gene. Indeed, a gene present in a given organism can be lost and replaced by a nonorthologous paralog coding for a protein with similar or identical function (see, e.g., [102]). In addition, any time along the cellular evolution, a new enzymatic activity, or a new enzymatic mechanism can be inherited from a lateral gene transfer from an organism living in endosymbiosis or in symbiosis within the same environment. Lateral gene transfer between Bacteria and Archaea or between Prokaryotae and Eukarya are frequent $[158,159]$. In all cases, the driving force is to optimize an ad hoc function required by the novel needs of the cell and according to the evolving cellular physiology and/or of growth conditions. In the particular case of tRNA modification, the need is to constantly adapt and preserve the stability of the overall architecture and consequently the functionality of the tRNA molecules according to the growing conditions as well as the physiological changes that occur all along the complex evolution process.

To conclude, this review shows the complexity of tRNA modification enzymes evolution, which makes genome annotation a difficult task $[160,161]$ and prompts to start studies on the emergence and evolution of enzymes catalyzing the formation of a given modified nucleotide at a given conserved position of the tRNA molecule. 
Funding: This research received no external funding.

Institutional Review Board Statement: Not applicable.

Informed Consent Statement: Not applicable.

Data Availability Statement: Not applicable.

Acknowledgments: We thank Eric Westhof for advice, for helping at generating Figure 3C, and for critical reading of the manuscript; André Feller for helping at generating the figures; and Dany Van Elder for helping at managing the references. We acknowledge the referees for improvements to the manuscript.

Conflicts of Interest: The authors declare no conflict of interest.

\section{References}

1. Westhof, E.; Auffinger, P. tRNA stucture. In Citable Reviews in the Life Sciences; John Wiley \& Sons Ltd.: Chichester, UK, 2001; pp. 1-11. [CrossRef]

2. Giegé, R.; Jühling, F.; Pütz, J.; Stadler, P.; Sauter, C.; Florentz, C. Structure of transfer RNAs: Similarity and variability. Wiley Interdiscip. Rev. RNA 2012, 3, 37-61. [CrossRef]

3. Lorenz, C.; Lünse, C.E.; Mörl, M. tRNA Modifications: Impact on Structure and Thermal Adaptation. Biomolecules 2017, 7, 35. [CrossRef]

4. Väre, V.Y.; Eruysal, E.R.; Narendran, A.; Sarachan, K.L.; Agris, P.F. Chemical and Conformational Diversity of Modified Nucleosides Affects tRNA Structure and Function. Biomolecules 2017, 7, 29. [CrossRef]

5. Steinberg, S.; Leclerc, F.; Cedergren, R. Structural rules and conformational compensations in the tRNA L-form. J. Mol. Biol. 1997, 266, 269-282. [CrossRef]

6. Watanabe, Y.; Suematsu, T.; Ohtsuki, T. Losing the stem-loop structure from metazoan mitochondrial tRNAs and co-evolution of interacting factors. Front. Genet. 2014, 5, 109. [CrossRef]

7. Dick, T.P.; Schamel, W.A. Molecular evolution of transfer RNA from two precursor hairpins: Implications for the origin of protein synthesis. J. Mol. Evol. 1995, 41, 1-9. [CrossRef]

8. Ardell, D.H. Computational analysis of tRNA identity. FEBS Lett. 2010, 584, 325-333. [CrossRef]

9. Jühling, F.; Mörl, M.; Hartmann, R.K.; Sprinzl, M.; Stadler, P.F.; Pütz, J. tRNAdb 2009: Compilation of tRNA sequences and tRNA genes. Nucleic Acids Res. 2009, 37, D159-D162. [CrossRef]

10. Boccaletto, P.; Machnicka, M.A.; Purta, E.; Piatkowski, P.; Baginski, B.; Wirecki, T.K.; de Crecy-Lagard, V.; Ross, R.; Limbach, P.A.; Kotter, A.; et al. MODOMICS: A database of RNA modification pathways. 2017 update. Nucleic Acids Res. 2018, 46, D303-D307. [CrossRef]

11. Westhof, E.; Dumas, P.; Moras, D. Crystallographic refinement of yeast aspartic acid transfer RNA. J. Mol. Biol. 1985, 184, 119-145. [CrossRef]

12. Romby, P.; Carbon, P.; Westhof, E.; Ehresmann, C.; Ebel, J.P.; Ehresmann, B.; Giegé, R. Importance of conserved residues for the conformation of the T-loop in tRNAs. J. Biomol. Struct. Dyn. 1987, 5, 669-687. [CrossRef]

13. Shi, H.; Moore, P.B. The crystal structure of yeast phenylalanine tRNA at 1.93 A resolution: A classic structure revisited. RNA 2000, 6, 1091-1105. [CrossRef]

14. Basavappa, R.; Sigler, P.B. The 3 A crystal structure of yeast initiator tRNA: Functional implications in initiator/elongator discrimination. EMBO J. 1991, 10, 3105-3111. [CrossRef]

15. Quigley, G.J.; Rich, A. Structural domains of transfer RNA molecules. Science 1976, 194, 796-806. [CrossRef]

16. Levitt, M. Detailed molecular model for transfer ribonucleic acid. Nature 1969, 224, 759-763. [CrossRef]

17. Oliva, R.; Cavallo, L.; Tramontano, A. Accurate energies of hydrogen bonded nucleic acid base pairs and triplets in tRNA tertiary interactions. Nucleic Acids Res. 2006, 34, 865-879. [CrossRef]

18. Davis, D.R. Stabilization of RNA stacking by pseudouridine. Nucleic Acids Res. 1995, 23, 5020-5026. [CrossRef]

19. Westhof, E.; Dumas, P.; Moras, D. Hydration of transfer RNA molecules: A crystallographic study. Biochimie 1988, 70, 145-165. [CrossRef]

20. Hori, H.; Kawamura, T.; Awai, T.; Ochi, A.; Yamagami, R.; Tomikawa, C.; Hirata, A. Transfer RNA Modification Enzymes from Thermophiles and Their Modified Nucleosides in tRNA. Microorganisms 2018, 6, 110. [CrossRef]

21. Rose, S.; Auxilien, S.; Havelund, J.F.; Kirpekar, F.; Huber, H.; Grosjean, H.; Douthwaite, S. The hyperthermophilic partners Nanoarchaeum and Ignicoccus stabilize their tRNA T-loops via different but structurally equivalent modifications. Nucleic Acids Res. 2020, 48, 6906-6918. [CrossRef]

22. Shigi, N. Biosynthesis and functions of sulfur modifications in tRNA. Front. Genet. 2014, 5, 67. [CrossRef]

23. Kawai, G.; Yamamoto, Y.; Kamimura, T.; Masegi, T.; Sekine, M.; Hata, T.; Iimori, T.; Watanabe, T.; Miyazawa, T.; Yokoyama, S. Conformational rigidity of specific pyrimidine residues in tRNA arises from posttranscriptional modifications that enhance steric interaction between the base and the 2'-hydroxyl group. Biochemistry 1992, 31, 1040-1046. [CrossRef] 
24. Clouet-d'Orval, B.; Gaspin, C.; Mougin, A. Two different mechanisms for tRNA ribose methylation in Archaea: A short survey. Biochimie 2005, 87, 889-895. [CrossRef]

25. Edmonds, C.G.; Crain, P.F.; Gupta, R.; Hashizume, T.; Hocart, C.H.; Kowalak, J.A.; Pomerantz, S.C.; Stetter, K.O.; McCloskey, J.A. Posttranscriptional modification of tRNA in thermophilic archaea (Archaebacteria). J. Bacteriol 1991, 173, 3138-3148. [CrossRef]

26. Keller, P.; Freund, I.; Marchand, V.; Bec, G.; Huang, R.; Motorin, Y.; Eigenbrod, T.; Dalpke, A.; Helm, M. Double methylation of tRNA-U54 to 2'-O-methylthymidine (Tm) synergistically decreases immune response by Toll-like receptor 7. Nucleic Acids Res. 2018, 46, 9764-9775. [CrossRef]

27. Gupta, R. Halobacterium volcanii tRNAs. Identification of 41 tRNAs covering all amino acids, and the sequences of 33 class I tRNAs. J. Biol. Chem. 1984, 259, 9461-9471. [CrossRef]

28. Grosjean, H.; Gaspin, C.; Marck, C.; Decatur, W.A.; de Crécy-Lagard, V. RNomics and Modomics in the halophilic archaea Haloferax volcanii: Identification of RNA modification genes. BMC Genom. 2008, 9, 470. [CrossRef]

29. Wolff, P.; Villette, C.; Zumsteg, J.; Heintz, D.; Antoine, L.; Chane-Woon-Ming, B.; Droogmans, L.; Grosjean, H.; Westhof, E. Comparative patterns of modified nucleotides in individual tRNA species from a mesophilic and two thermophilic archaea. $R N A$ 2020, 26, 1957-1975. [CrossRef]

30. Nobles, K.N.; Yarian, C.S.; Liu, G.; Guenther, R.H.; Agris, P.F. Highly conserved modified nucleosides influence $\mathrm{Mg}^{2+}$-dependent tRNA folding. Nucleic Acids Res. 2002, 30, 4751-4760. [CrossRef]

31. Ayadi, L.; Galvanin, A.; Pichot, F.; Marchand, V.; Motorin, Y. RNA ribose methylation (2'-O-methylation): Occurrence, biosynthesis and biological functions. Biochim. Biophys. Acta Gene. Regul. Mech. 2019, 1862, 253-269. [CrossRef]

32. Nureki, O.; Watanabe, K.; Fukai, S.; Ishii, R.; Endo, Y.; Hori, H.; Yokoyama, S. Deep knot structure for construction of active site and cofactor binding site of tRNA modification enzyme. Structure 2004, 12, 593-602. [CrossRef]

33. Galperin, M.Y.; Wolf, Y.I.; Makarova, K.S.; Vera Alvarez, R.; Landsman, D.; Koonin, E.V. COG database update: Focus on microbial diversity, model organisms, and widespread pathogens. Nucleic Acids Res. 2020. [CrossRef]

34. Hori, H.; Yamazaki, N.; Matsumoto, T.; Watanabe, Y.; Ueda, T.; Nishikawa, K.; Kumagai, I.; Watanabe, K. Substrate recognition of tRNA (Guanosine-2'-)-methyltransferase from Thermus thermophilus HB27. J. Biol. Chem. 1998, 273, 25721-25727. [CrossRef]

35. Persson, B.C.; Jäger, G.; Gustafsson, C. The spoU gene of Escherichia coli, the fourth gene of the spoT operon, is essential for tRNA (Gm18) 2'-O-methyltransferase activity. Nucleic Acids Res. 1997, 25, 4093-4097. [CrossRef]

36. Hori, H.; Kubota, S.; Watanabe, K.; Kim, J.M.; Ogasawara, T.; Sawasaki, T.; Endo, Y. Aquifex aeolicus tRNA (Gm18) methyltransferase has unique substrate specificity. TRNA recognition mechanism of the enzyme. J. Biol. Chem. 2003, 278, 25081-25090. [CrossRef]

37. Hori, H. Transfer RNA methyltransferases with a SpoU-TrmD (SPOUT) fold and their modified nucleosides in tRNA. Biomolecules 2017, 7, 23. [CrossRef]

38. Cavaillé, J.; Chetouani, F.; Bachellerie, J.P. The yeast Saccharomyces cerevisiae YDL112w ORF encodes the putative 2'-O-ribose methyltransferase catalyzing the formation of Gm18 in tRNAs. RNA 1999, 5, 66-81. [CrossRef]

39. De Crécy-Lagard, V.; Boccaletto, P.; Mangleburg, C.G.; Sharma, P.; Lowe, T.M.; Leidel, S.A.; Bujnicki, J.M. Matching tRNA modifications in humans to their known and predicted enzymes. Nucleic Acids Res. 2019, 47, 2143-2159. [CrossRef]

40. Omer, A.D.; Lowe, T.M.; Russell, A.G.; Ebhardt, H.; Eddy, S.R.; Dennis, P.P. Homologs of small nucleolar RNAs in Archaea. Science 2000, 288, 517-522. [CrossRef]

41. Lui, L.M.; Uzilov, A.V.; Bernick, D.L.; Corredor, A.; Lowe, T.M.; Dennis, P.P. Methylation guide RNA evolution in archaea: Structure, function and genomic organization of $110 \mathrm{C} / \mathrm{D}$ box sRNA families across six Pyrobaculum species. Nucleic Acids Res. 2018, 46, 5678-5691. [CrossRef]

42. Anderson, J.; Droogmans, L. Biosynthesis and function of 1-methyladenosine in transfer RNA. In Fine-Tuning of RNA Functions by Modification and Editing; Grosjean, H., Ed.; Springer: Heidelberg/Berlin, Germany, 2005; pp. 121-139.

43. Swinehart, W.E.; Jackman, J.E. Diversity in mechanism and function of tRNA methyltransferases. RNA Biol. 2015, 12, 398-411. [CrossRef] [PubMed]

44. Dégut, C.; Ponchon, L.; Folly-Klan, M.; Barraud, P.; Tisné, C. The m1A(58) modification in eubacterial tRNA: An overview of tRNA recognition and mechanism of catalysis by TrmI. Biophys. Chem. 2016, 210, 27-34. [CrossRef] [PubMed]

45. Oerum, S.; Dégut, C.; Barraud, P.; Tisné, C. m1A Post-Transcriptional Modification in tRNAs. Biomolecules 2017, 7, 20. [CrossRef] [PubMed]

46. Shima, H.; Igarashi, K. N 1-methyladenosine (m1A) RNA modification: The key to ribosome control. J. Biochem. 2020, 167, 535-539. [CrossRef]

47. Droogmans, L.; Roovers, M.; Bujnicki, J.M.; Tricot, C.; Hartsch, T.; Stalon, V.; Grosjean, H. Cloning and characterization of tRNA (m1A58) methyltransferase (TrmI) from Thermus thermophilus HB27, a protein required for cell growth at extreme temperatures. Nucleic Acids Res. 2003, 31, 2148-2156. [CrossRef]

48. Barraud, P.; Golinelli-Pimpaneau, B.; Atmanene, C.; Sanglier, S.; Van Dorsselaer, A.; Droogmans, L.; Dardel, F.; Tisné, C. Crystal structure of Thermus thermophilus tRNA m1A58 methyltransferase and biophysical characterization of its interaction with tRNA. J. Mol. Biol. 2008, 377, 535-550. [CrossRef] [PubMed]

49. Takuma, H.; Ushio, N.; Minoji, M.; Kazayama, A.; Shigi, N.; Hirata, A.; Tomikawa, C.; Ochi, A.; Hori, H. Substrate tRNA recognition mechanism of eubacterial tRNA (m1A58) methyltransferase (TrmI). J. Biol. Chem. 2015, 290, 5912-5925. [CrossRef] 
50. Grosjean, H.; Edqvist, J.; Stråby, K.B.; Giegé, R. Enzymatic formation of modified nucleosides in tRNA: Dependence on tRNA architecture. J. Mol. Biol. 1996, 255, 67-85. [CrossRef]

51. Anderson, J.; Phan, L.; Cuesta, R.; Carlson, B.A.; Pak, M.; Asano, K.; Björk, G.R.; Tamame, M.; Hinnebusch, A.G. The essential Gcd10p-Gcd14p nuclear complex is required for 1-methyladenosine modification and maturation of initiator methionyl-tRNA. Genes Dev. 1998, 12, 3650-3662. [CrossRef]

52. Ozanick, S.; Krecic, A.; Andersland, J.; Anderson, J.T. The bipartite structure of the tRNA m1A58 methyltransferase from S. cerevisiae is conserved in humans. RNA 2005, 11, 1281-1290. [CrossRef]

53. Wang, M.; Zhu, Y.; Wang, C.; Fan, X.; Jiang, X.; Ebrahimi, M.; Qiao, Z.; Niu, L.; Teng, M.; Li, X. Crystal structure of the two-subunit tRNA m(1)A58 methyltransferase TRM6-TRM61 from Saccharomyces cerevisiae. Sci. Rep. 2016, 6, 32562. [CrossRef] [PubMed]

54. Guy, M.P.; Phizicky, E.M. Two-subunit enzymes involved in eukaryotic post-transcriptional tRNA modification. RNA Biol. 2014, 11, 1608-1618. [CrossRef] [PubMed]

55. Roovers, M.; Wouters, J.; Bujnicki, J.M.; Tricot, C.; Stalon, V.; Grosjean, H.; Droogmans, L. A primordial RNA modification enzyme: The case of tRNA (m1A) methyltransferase. Nucleic Acids Res. 2004, 32, 465-476. [CrossRef] [PubMed]

56. Guelorget, A.; Barraud, P.; Tisné, C.; Golinelli-Pimpaneau, B. Structural comparison of tRNA m(1)A58 methyltransferases revealed different molecular strategies to maintain their oligomeric architecture under extreme conditions. BMC Struct. Biol. 2011, 11, 48. [CrossRef] [PubMed]

57. Guelorget, A.; Roovers, M.; Guérineau, V.; Barbey, C.; Li, X.; Golinelli-Pimpaneau, B. Insights into the hyperthermostability and unusual region-specificity of archaeal Pyrococcus abyssi tRNA m1A57/58 methyltransferase. Nucleic Acids Res. 2010, 38, 6206-6218. [CrossRef]

58. Hamdane, D.; Guelorget, A.; Guérineau, V.; Golinelli-Pimpaneau, B. Dynamics of RNA modification by a multi-site-specific tRNA methyltransferase. Nucleic Acids Res. 2014, 42, 11697-11706. [CrossRef]

59. Grosjean, H.; Constantinesco, F.; Foiret, D.; Benachenhou, N. A novel enzymatic pathway leading to 1-methylinosine modification in Haloferax volcanii tRNA. Nucleic Acids Res. 1995, 23, 4312-4319. [CrossRef]

60. Dixit, S.; Henderson, J.C.; Alfonzo, J.D. Multi-Substrate Specificity and the Evolutionary Basis for Interdependence in tRNA Editing and Methylation Enzymes. Front. Genet. 2019, 10, 104. [CrossRef]

61. Agris, P.F. The importance of being modified: Roles of modified nucleosides and $\mathrm{Mg}^{2+}$ in RNA structure and function. Prog. Nucleic Acid Res. Mol. Biol. 1996, 53, 79-129. [CrossRef]

62. Auxilien, S.; Keith, G.; Le Grice, S.F.; Darlix, J.L. Role of post-transcriptional modifications of primer tRNALys,3 in the fidelity and efficacy of plus strand DNA transfer during HIV-1 reverse transcription. J. Biol. Chem. 1999, 274, 4412-4420. [CrossRef]

63. Liu, F.; Clark, W.; Luo, G.; Wang, X.; Fu, Y.; Wei, J.; Wang, X.; Hao, Z.; Dai, Q.; Zheng, G.; et al. ALKBH1-Mediated tRNA Demethylation Regulates Translation. Cell 2016, 167, 816-828.e16. [CrossRef] [PubMed]

64. Zhang, C.; Jia, G. Reversible RNA Modification N(1)-methyladenosine (m(1)A) in mRNA and tRNA. Genom. Proteom. Bioinform. 2018, 16, 155-161. [CrossRef] [PubMed]

65. Renalier, M.H.; Joseph, N.; Gaspin, C.; Thebault, P.; Mougin, A. The Cm56 tRNA modification in archaea is catalyzed either by a specific 2'-O-methylase, or a C/D sRNP. RNA 2005, 11, 1051-1063. [CrossRef] [PubMed]

66. Constantinesco, F.; Motorin, Y.; Grosjean, H. Transfer RNA modification enzymes from Pyrococcus furiosus: Detection of the enzymatic activities in vitro. Nucleic Acids Res. 1999, 27, 1308-1315. [CrossRef]

67. Tkaczuk, K.L.; Dunin-Horkawicz, S.; Purta, E.; Bujnicki, J.M. Structural and evolutionary bioinformatics of the SPOUT superfamily of methyltransferases. BMC Bioinform. 2007, 8, 73. [CrossRef]

68. Tomkuvienè, M.; Ličytè, J.; Olendraitè, I.; Liutkevičiūtè, Z.; Clouet-d'Orval, B.; Klimašauskas, S. Archaeal fibrillarin-Nop5 heterodimer 2'-O-methylates RNA independently of the C/D guide RNP particle. RNA 2017, 23, 1329-1337. [CrossRef] [PubMed]

69. Nurse, K.; Wrzesinski, J.; Bakin, A.; Lane, B.G.; Ofengand, J. Purification, cloning, and properties of the tRNA psi 55 synthase from Escherichia coli. RNA 1995, 1, 102-112.

70. Becker, H.F.; Motorin, Y.; Planta, R.J.; Grosjean, H. The yeast gene YNL292w encodes a pseudouridine synthase (Pus4) catalyzing the formation of psi55 in both mitochondrial and cytoplasmic tRNAs. Nucleic Acids Res. 1997, 25, 4493-4499. [CrossRef]

71. Zucchini, C.; Strippoli, P.; Biolchi, A.; Solmi, R.; Lenzi, L.; D'Addabbo, P.; Carinci, P.; Valvassori, L. The human TruB family of pseudouridine synthase genes, including the Dyskeratosis Congenita 1 gene and the novel member TRUB1. Int. J. Mol. Med. 2003, 11, 697-704. [CrossRef]

72. Pan, H.; Agarwalla, S.; Moustakas, D.T.; Finer-Moore, J.; Stroud, R.M. Structure of tRNA pseudouridine synthase TruB and its RNA complex: RNA recognition through a combination of rigid docking and induced fit. Proc. Natl. Acad. Sci. USA 2003, 100, 12648-12653. [CrossRef]

73. Phannachet, K.; Elias, Y.; Huang, R.H. Dissecting the roles of a strictly conserved tyrosine in substrate recognition and catalysis by pseudouridine 55 synthase. Biochemistry 2005, 44, 15488-15494. [CrossRef] [PubMed]

74. Hoang, C.; Hamilton, C.S.; Mueller, E.G.; Ferré-D'Amaré, A.R. Precursor complex structure of pseudouridine synthase TruB suggests coupling of active site perturbations to an RNA-sequestering peripheral protein domain. Protein Sci. 2005, 14, $2201-2206$. [CrossRef] [PubMed]

75. Hur, S.; Stroud, R.M.; Finer-Moore, J. Substrate recognition by RNA 5-methyluridine methyltransferases and pseudouridine synthases: A structural perspective. J. Biol. Chem. 2006, 281, 38969-38973. [CrossRef] [PubMed] 
76. Gu, X.; Yu, M.; Ivanetich, K.M.; Santi, D.V. Molecular recognition of tRNA by tRNA pseudouridine 55 synthase. Biochemistry 1998, 37, 339-343. [CrossRef] [PubMed]

77. Keffer-Wilkes, L.C.; Veerareddygari, G.R.; Kothe, U. RNA modification enzyme TruB is a tRNA chaperone. Proc. Natl. Acad. Sci. USA 2016, 113, 14306-14311. [CrossRef]

78. Hamma, T.; Ferré-D'Amaré, A.R. The box H/ACA ribonucleoprotein complex: Interplay of RNA and protein structures in post-transcriptional RNA modification. J. Biol. Chem. 2010, 285, 805-809. [CrossRef]

79. Yu, Y.T.; Meier, U.T. RNA-guided isomerization of uridine to pseudouridine-Pseudouridylation. RNA Biol. 2014, 11, 1483-1494. [CrossRef]

80. Spenkuch, F.; Motorin, Y.; Helm, M. Pseudouridine: Still mysterious, but never a fake (uridine)! RNA Biol. 2014, 11, 1540-1554. [CrossRef]

81. Roovers, M.; Hale, C.; Tricot, C.; Terns, M.P.; Terns, R.M.; Grosjean, H.; Droogmans, L. Formation of the conserved pseudouridine at position 55 in archaeal tRNA. Nucleic Acids Res. 2006, 34, 4293-4301. [CrossRef]

82. Gurha, P.; Joardar, A.; Chaurasia, P.; Gupta, R. Differential roles of archaeal box H/ACA proteins in guide RNA-dependent and independent pseudouridine formation. RNA Biol. 2007, 4, 101-109. [CrossRef]

83. Gurha, P.; Gupta, R. Archaeal Pus10 proteins can produce both pseudouridine 54 and 55 in tRNA. RNA 2008, 14, 2521-2527. [CrossRef]

84. Tillault, A.S.; Fourmann, J.B.; Loegler, C.; Wieden, H.J.; Kothe, U.; Charpentier, B. Contribution of two conserved histidines to the dual activity of archaeal RNA guide-dependent and -independent pseudouridine synthase Cbf5. RNA 2015, 21, 1233-1239. [CrossRef]

85. Muller, S.; Fourmann, J.B.; Loegler, C.; Charpentier, B.; Branlant, C. Identification of determinants in the protein partners aCBF5 and aNOP10 necessary for the tRNA:Psi55-synthase and RNA-guided RNA:Psi-synthase activities. Nucleic Acids Res. 2007, 35, 5610-5624. [CrossRef] [PubMed]

86. Fujikane, R.; Behm-Ansmant, I.; Tillault, A.S.; Loegler, C.; Igel-Bourguignon, V.; Marguet, E.; Forterre, P.; Branlant, C.; Motorin, Y.; Charpentier, B. Contribution of protein Gar1 to the RNA-guided and RNA-independent rRNA: $\Psi$-synthase activities of the archaeal Cbf5 protein. Sci. Rep. 2018, 8, 13815. [CrossRef] [PubMed]

87. Kamalampeta, R.; Kothe, U. Archaeal proteins Nop10 and Gar1 increase the catalytic activity of Cbf5 in pseudouridylating tRNA. Sci. Rep. 2012, 2, 663. [CrossRef] [PubMed]

88. Blaby, I.K.; Majumder, M.; Chatterjee, K.; Jana, S.; Grosjean, H.; de Crécy-Lagard, V.; Gupta, R. Pseudouridine formation in archaeal RNAs: The case of Haloferax volcanii. RNA 2011, 17, 1367-1380. [CrossRef] [PubMed]

89. Watanabe, Y.; Gray, M.W. Evolutionary appearance of genes encoding proteins associated with box H/ACA snoRNAs: cbf5p in Euglena gracilis, an early diverging eukaryote, and candidate Gar1p and Nop10p homologs in archaebacteria. Nucleic Acids Res. 2000, 28, 2342-2352. [CrossRef]

90. Fitzek, E.; Joardar, A.; Gupta, R.; Geisler, M. Evolution of Eukaryal and Archaeal Pseudouridine Synthase Pus10. J. Mol. Evol. 2018, 86, 77-89. [CrossRef]

91. Mukhopadhyay, S.; Deogharia, M.; Gupta, R. Mammalian nuclear TRUB1, mitochondrial TRUB2 and cytoplasmic PUS10 produce conserved pseudouridine 55 in different sets of tRNA. RNA 2020. [CrossRef]

92. Ny, T.; Björk, G.R. Cloning and restriction mapping of the trmA gene coding for transfer ribonucleic acid (5-methyluridine)methyltransferase in Escherichia coli K-12. J. Bacteriol. 1980, 142, 371-379. [CrossRef]

93. Persson, B.C.; Gustafsson, C.; Berg, D.E.; Björk, G.R. The gene for a tRNA modifying enzyme, m5U54-methyltransferase, is essential for viability in Escherichia coli. Proc. Natl. Acad. Sci. USA 1992, 89, 3995-3998. [CrossRef] [PubMed]

94. Kealey, J.T.; Gu, X.; Santi, D.V. Enzymatic mechanism of tRNA (m5U54)methyltransferase. Biochimie 1994, 76, 1133-1142. [CrossRef]

95. Keffer-Wilkes, L.C.; Soon, E.F.; Kothe, U. The methyltransferase TrmA facilitates tRNA folding through interaction with its RNA-binding domain. Nucleic Acids Res. 2020, 48, 7981-7990. [CrossRef] [PubMed]

96. Nordlund, M.E.; Johansson, J.O.; von Pawel-Rammingen, U.; Byström, A.S. Identification of the TRM2 gene encoding the tRNA(m5U54)methyltransferase of Saccharomyces cerevisiae. RNA 2000, 6, 844-860. [CrossRef] [PubMed]

97. Carter, J.M.; Emmett, W.; Mozos, I.R.; Kotter, A.; Helm, M.; Ule, J.; Hussain, S. FICC-Seq: A method for enzyme-specified profiling of methyl-5-uridine in cellular RNA. Nucleic Acids Res. 2019, 47, e113. [CrossRef]

98. Urbonavicius, J.; Brochier-Armanet, C.; Skouloubris, S.; Myllykallio, H.; Grosjean, H. In Vitro detection of the enzymatic activity of folate-dependent tRNA (Uracil-54,-C5)-methyltransferase: Evolutionary implications. Methods Enzymol. 2007, 425, 103-119. [CrossRef]

99. Urbonavicius, J.; Skouloubris, S.; Myllykallio, H.; Grosjean, H. Identification of a novel gene encoding a flavin-dependent tRNA:m5U methyltransferase in bacteria-Evolutionary implications. Nucleic Acids Res. 2005, 33, 3955-3964. [CrossRef]

100. Hamdane, D.; Grosjean, H.; Fontecave, M. Flavin-Dependent Methylation of RNAs: Complex Chemistry for a Simple Modification. J. Mol. Biol. 2016, 428, 4867-4881. [CrossRef]

101. Grosjean, H.; Breton, M.; Sirand-Pugnet, P.; Tardy, F.; Thiaucourt, F.; Citti, C.; Barré, A.; Yoshizawa, S.; Fourmy, D.; de CrécyLagard, V.; et al. Predicting the minimal translation apparatus: Lessons from the reductive evolution of mollicutes. PLoS Genet. 2014, 10, e1004363. [CrossRef] 
102. Sirand-Pugnet, P.; Brégeon, D.; Béven, L.; Goyenvalle, C.; Blanchard, A.; Rose, S.; Grosjean, H.; Douthwaite, S.; Hamdane, D.; Crécy-Lagard, V. Reductive Evolution and Diversification of C5-Uracil Methylation in the Nucleic Acids of Mollicutes. Biomolecules 2020, 10, 587. [CrossRef]

103. Urbonavicius, J.; Auxilien, S.; Walbott, H.; Trachana, K.; Golinelli-Pimpaneau, B.; Brochier-Armanet, C.; Grosjean, H. Acquisition of a bacterial RumA-type tRNA(uracil-54, C5)-methyltransferase by Archaea through an ancient horizontal gene transfer. Mol. Microbiol. 2008, 67, 323-335. [CrossRef] [PubMed]

104. Lee, T.T.; Agarwalla, S.; Stroud, R.M. Crystal structure of RumA, an iron-sulfur cluster containing E. coli ribosomal RNA 5-methyluridine methyltransferase. Structure 2004, 12, 397-407. [CrossRef] [PubMed]

105. Auxilien, S.; Rasmussen, A.; Rose, S.; Brochier-Armanet, C.; Husson, C.; Fourmy, D.; Grosjean, H.; Douthwaite, S. Specificity shifts in the rRNA and tRNA nucleotide targets of archaeal and bacterial m5U methyltransferases. RNA 2011, 17, 45-53. [CrossRef] [PubMed]

106. Sengupta, R.; Vainauskas, S.; Yarian, C.; Sochacka, E.; Malkiewicz, A.; Guenther, R.H.; Koshlap, K.M.; Agris, P.F. Modified constructs of the tRNA TPsiC domain to probe substrate conformational requirements of m(1)A(58) and m(5)U(54) tRNA methyltransferases. Nucleic Acids Res. 2000, 28, 1374-1380. [CrossRef]

107. Alian, A.; Lee, T.T.; Griner, S.L.; Stroud, R.M.; Finer-Moore, J. Structure of a TrmA-RNA complex: A consensus RNA fold contributes to substrate selectivity and catalysis in m5U methyltransferases. Proc. Natl. Acad. Sci. USA 2008, 105, 6876-6881. [CrossRef]

108. Walbott, H.; Leulliot, N.; Grosjean, H.; Golinelli-Pimpaneau, B. The crystal structure of Pyrococcus abyssi tRNA (uracil-54, C5)-methyltransferase provides insights into its tRNA specificity. Nucleic Acids Res. 2008, 36, 4929-4940. [CrossRef]

109. Yamagami, R.; Yamashita, K.; Nishimasu, H.; Tomikawa, C.; Ochi, A.; Iwashita, C.; Hirata, A.; Ishitani, R.; Nureki, O.; Hori, H. The tRNA recognition mechanism of folate/FAD-dependent tRNA methyltransferase (TrmFO). J. Biol. Chem. 2012, 287, 42480-42494. [CrossRef]

110. Gross, H.J.; Simsek, M.; Raba, M.; Limburg, K.; Heckman, J.; Raj Bhandary, U.L. 2'-O-methyl ribothymidine: A component of rabbit liver lysine transfer RNA. Nucleic Acids Res. 1974, 1, 35-43. [CrossRef]

111. Shigi, N.; Sakaguchi, Y.; Asai, S.; Suzuki, T.; Watanabe, K. Common thiolation mechanism in the biosynthesis of tRNA thiouridine and sulphur-containing cofactors. EMBO J. 2008, 27, 3267-3278. [CrossRef]

112. Čavužić, M.; Liu, Y. Biosynthesis of Sulfur-Containing tRNA Modifications: A Comparison of Bacterial, Archaeal, and Eukaryotic Pathways. Biomolecules 2017, 7, 27. [CrossRef]

113. Shigi, N.; Sakaguchi, Y.; Suzuki, T.; Watanabe, K. Identification of two tRNA thiolation genes required for cell growth at extremely high temperatures. J. Biol. Chem. 2006, 281, 14296-14306. [CrossRef] [PubMed]

114. Shigi, N.; Suzuki, T.; Tamakoshi, M.; Oshima, T.; Watanabe, K. Conserved bases in the TPsi C loop of tRNA are determinants for thermophile-specific 2-thiouridylation at position 54. J. Biol. Chem. 2002, 277, 39128-39135. [CrossRef] [PubMed]

115. Tomikawa, C.; Yokogawa, T.; Kanai, T.; Hori, H. N7-Methylguanine at position 46 (m7G46) in tRNA from Thermus thermophilus is required for cell viability at high temperatures through a tRNA modification network. Nucleic Acids Res. 2010, 38, 942-957. [CrossRef] [PubMed]

116. Joardar, A.; Jana, S.; Fitzek, E.; Gurha, P.; Majumder, M.; Chatterjee, K.; Geisler, M.; Gupta, R. Role of forefinger and thumb loops in production of $\Psi 54$ and $\Psi 55$ in tRNAs by archaeal Pus10. RNA 2013, 19, 1279-1294. [CrossRef] [PubMed]

117. Deogharia, M.; Mukhopadhyay, S.; Joardar, A.; Gupta, R. The human ortholog of archaeal Pus10 produces pseudouridine 54 in select tRNAs where its recognition sequence contains a modified residue. RNA 2019, 25, 336-351. [CrossRef]

118. McCleverty, C.J.; Hornsby, M.; Spraggon, G.; Kreusch, A. Crystal structure of human Pus10, a novel pseudouridine synthase. J. Mol. Biol. 2007, 373, 1243-1254. [CrossRef]

119. Aravind, L.; Koonin, E.V. THUMP-A predicted RNA-binding domain shared by 4-thiouridine, pseudouridine synthases and RNA methylases. Trends Biochem. Sci. 2001, 26, 215-217. [CrossRef]

120. Gabant, G.; Auxilien, S.; Tuszynska, I.; Locard, M.; Gajda, M.J.; Chaussinand, G.; Fernandez, B.; Dedieu, A.; Grosjean, H.; Golinelli-Pimpaneau, B.; et al. THUMP from archaeal tRNA:m22G10 methyltransferase, a genuine autonomously folding domain. Nucleic Acids Res. 2006, 34, 2483-2494. [CrossRef]

121. Waterman, D.G.; Ortiz-Lombardía, M.; Fogg, M.J.; Koonin, E.V.; Antson, A.A. Crystal structure of Bacillus anthracis Thil, a tRNA-modifying enzyme containing the predicted RNA-binding THUMP domain. J. Mol. Biol. 2006, 356, 97-110. [CrossRef]

122. Fislage, M.; Roovers, M.; Tuszynska, I.; Bujnicki, J.M.; Droogmans, L.; Versées, W. Crystal structures of the tRNA:m2G6 methyltransferase Trm14/TrmN from two domains of life. Nucleic Acids Res. 2012, 40, 5149-5161. [CrossRef]

123. Neumann, P.; Lakomek, K.; Naumann, P.T.; Erwin, W.M.; Lauhon, C.T.; Ficner, R. Crystal structure of a 4-thiouridine synthetaseRNA complex reveals specificity of tRNA U8 modification. Nucleic Acids Res. 2014, 42, 6673-6685. [CrossRef] [PubMed]

124. Hirata, A.; Nishiyama, S.; Tamura, T.; Yamauchi, A.; Hori, H. Structural and functional analyses of the archaeal tRNA $\mathrm{m} 2 \mathrm{G} / \mathrm{m} 22 \mathrm{G} 10$ methyltransferase aTrm11 provide mechanistic insights into site specificity of a tRNA methyltransferase that contains common RNA-binding modules. Nucleic Acids Res. 2016, 44, 6377-6390. [CrossRef] [PubMed]

125. Chatterjee, K.; Blaby, I.K.; Thiaville, P.C.; Majumder, M.; Grosjean, H.; Yuan, Y.A.; Gupta, R.; de Crécy-Lagard, V. The archaeal COG1901/DUF358 SPOUT-methyltransferase members, together with pseudouridine synthase Pus10, catalyze the formation of 1-methylpseudouridine at position 54 of tRNA. RNA 2012, 18, 421-433. [CrossRef] 
126. Wurm, J.P.; Griese, M.; Bahr, U.; Held, M.; Heckel, A.; Karas, M.; Soppa, J.; Wöhnert, J. Identification of the enzyme responsible for N1-methylation of pseudouridine 54 in archaeal tRNAs. RNA 2012, 18, 412-420. [CrossRef]

127. Chen, H.Y.; Yuan, Y.A. Crystal structure of Mj1640/DUF358 protein reveals a putative SPOUT-class RNA methyltransferase. J. Mol. Cell Biol. 2010, 2, 366-374. [CrossRef]

128. Forterre, P.; Gribaldo, S.; Brochier-Armanet, C. Happy together: Genomic insights into the unique Nanoarchaeum/Ignicoccus association. J. Biol. 2009, 8, 7. [CrossRef]

129. Kuchino, Y.; Ihara, M.; Yabusaki, Y.; Nishimura, S. Initiator tRNAs from archaebacteria show common unique sequence characteristics. Nature 1982, 298, 684-685. [CrossRef]

130. Tang, T.H.; Polacek, N.; Zywicki, M.; Huber, H.; Brugger, K.; Garrett, R.; Bachellerie, J.P.; Hüttenhofer, A. Identification of novel non-coding RNAs as potential antisense regulators in the archaeon Sulfolobus solfataricus. Mol. Microbiol. 2005, 55, 469-481. [CrossRef]

131. Zago, M.A.; Dennis, P.P.; Omer, A.D. The expanding world of small RNAs in the hyperthermophilic archaeon Sulfolobus solfataricus. Mol. Microbiol. 2005, 55, 1812-1828. [CrossRef]

132. Nishikura, K.; De Robertis, E.M. RNA processing in microinjected Xenopus oocytes. Sequential addition of base modifications in the spliced transfer RNA. J. Mol. Biol. 1981, 145, 405-420. [CrossRef]

133. Koski, R.A.; Clarkson, S.G. Synthesis and maturation of Xenopus laevis methionine tRNA gene transcripts in homologous cell-free extracts. J. Biol Chem. 1982, 257, 4514-4521. [CrossRef]

134. Jiang, H.Q.; Motorin, Y.; Jin, Y.X.; Grosjean, H. Pleiotropic effects of intron removal on base modification pattern of yeast $t R N A P h e:$ An in vitro study. Nucleic Acids Res. 1997, 25, 2694-2701. [CrossRef] [PubMed]

135. Barraud, P.; Gato, A.; Heiss, M.; Catala, M.; Kellner, S.; Tisné, C. Time-resolved NMR monitoring of tRNA maturation. Nat. Commun. 2019, 10, 3373. [CrossRef] [PubMed]

136. Ishida, K.; Kunibayashi, T.; Tomikawa, C.; Ochi, A.; Kanai, T.; Hirata, A.; Iwashita, C.; Hori, H. Pseudouridine at position 55 in tRNA controls the contents of other modified nucleotides for low-temperature adaptation in the extreme-thermophilic eubacterium Thermus thermophilus. Nucleic Acids Res. 2011, 39, 2304-2318. [CrossRef]

137. Schultz, S.K.; Kothe, U. tRNA elbow modifications affect the tRNA pseudouridine synthase TruB and the methyltransferase TrmA. RNA 2020, 26, 1131-1142. [CrossRef]

138. Barraud, P.; Tisné, C. To be or not to be modified: Miscellaneous aspects influencing nucleotide modifications in tRNAs. IUBMB Life 2019, 71, 1126-1140. [CrossRef]

139. Hori, H. Regulatory Factors for tRNA Modifications in Extreme- Thermophilic Bacterium Thermus thermophilus. Front. Genet. 2019, 10, 204. [CrossRef]

140. Sokołowski, M.; Klassen, R.; Bruch, A.; Schaffrath, R.; Glatt, S. Cooperativity between different tRNA modifications and their modification pathways. Biochim. Biophys. Acta Gene Regul. Mech. 2018, 1861, 409-418. [CrossRef]

141. Han, L.; Phizicky, E.M. A rationale for tRNA modification circuits in the anticodon loop. RNA 2018, 24, 1277-1284. [CrossRef]

142. Perret, V.; Garcia, A.; Puglisi, J.; Grosjean, H.; Ebel, J.P.; Florentz, C.; Giegé, R. Conformation in solution of yeast tRNA(Asp) transcripts deprived of modified nucleotides. Biochimie 1990, 72, 735-743. [CrossRef]

143. Byrne, R.T.; Konevega, A.L.; Rodnina, M.V.; Antson, A.A. The crystal structure of unmodified tRNAPhe from Escherichia coli. Nucleic Acids Res. 2010, 38, 4154-4162. [CrossRef] [PubMed]

144. Nagaswamy, U.; Fox, G.E. Frequent occurrence of the T-loop RNA folding motif in ribosomal RNAs. RNA 2002, 8, 1112-1119. [CrossRef] [PubMed]

145. Fechter, P.; Rudinger-Thirion, J.; Florentz, C.; Giegé, R. Novel features in the tRNA-like world of plant viral RNAs. Cell Mol. Life Sci. 2001, 58, 1547-1561. [CrossRef] [PubMed]

146. Barends, S.; Björk, K.; Gultyaev, A.P.; de Smit, M.H.; Pleij, C.W.; Kraal, B. Functional evidence for D- and T-loop interactions in tmRNA. FEBS Lett. 2002, 514, 78-83. [CrossRef]

147. Becker, H.F.; Motorin, Y.; Florentz, C.; Giegé, R.; Grosjean, H. Pseudouridine and ribothymidine formation in the tRNA-like domain of turnip yellow mosaic virus RNA. Nucleic Acids Res. 1998, 26, 3991-3997. [CrossRef]

148. Ranaei-Siadat, E.; Fabret, C.; Seijo, B.; Dardel, F.; Grosjean, H.; Nonin-Lecomte, S. RNA-methyltransferase TrmA is a dual-specific enzyme responsible for C5-methylation of uridine in both tmRNA and tRNA. RNA Biol. 2013, 10, 572-578. [CrossRef]

149. Zagryadskaya, E.I.; Kotlova, N.; Steinberg, S.V. Key elements in maintenance of the tRNA L-shape. J. Mol. Biol. 2004, 340, 435-444. [CrossRef]

150. Zagryadskaya, E.I.; Doyon, F.R.; Steinberg, S.V. Importance of the reverse Hoogsteen base pair $54-58$ for tRNA function. Nucleic Acids Res. 2003, 31, 3946-3953. [CrossRef]

151. Kuhn, C.D. RNA versatility governs tRNA function: Why tRNA flexibility is essential beyond the translation cycle. Bioessays 2016, 38, 465-473. [CrossRef]

152. Levy, M.; Miller, S.L. The prebiotic synthesis of modified purines and their potential role in the RNA world. J. Mol. Evol. 1999, 48, 631-637. [CrossRef]

153. Cermakian, N.; Cedergren, R. Modified Nucleosides Always Were: An Evolutionary Model. In Modification and Editing of RNA; Grosjean, H., Benne, R., Eds.; ASM Press: Washington, DC, USA, 1998; pp. 535-541.

154. McKenney, K.M.; Alfonzo, J.D. From Prebiotics to Probiotics: The Evolution and Functions of tRNA Modifications. Life Basel $2016,6,13$. [CrossRef] [PubMed] 
155. Anantharaman, V.; Koonin, E.V.; Aravind, L. Comparative genomics and evolution of proteins involved in RNA metabolism. Nucleic Acids Res. 2002, 30, 1427-1464. [CrossRef] [PubMed]

156. McKenney, K.M.; Rubio, M.A.T.; Alfonzo, J.D. The Evolution of Substrate Specificity by tRNA Modification Enzymes. Enzymes 2017, 41, 51-88. [CrossRef] [PubMed]

157. Galperin, M.Y.; Walker, D.R.; Koonin, E.V. Analogous enzymes: Independent inventions in enzyme evolution. Genome Res. 1998, 8, 779-790. [CrossRef] [PubMed]

158. Soucy, S.M.; Huang, J.; Gogarten, J.P. Horizontal gene transfer: Building the web of life. Nat. Rev. Genet. 2015, 16, 472-482. [CrossRef] [PubMed]

159. Sieber, K.B.; Bromley, R.E.; Dunning Hotopp, J.C. Lateral gene transfer between prokaryotes and eukaryotes. Exp. Cell Res. 2017, 358, 421-426. [CrossRef]

160. Galperin, M.Y.; Koonin, E.V. Sources of systematic error in functional annotation of genomes: Domain rearrangement, nonorthologous gene displacement and operon disruption. Silico Biol. 1998, 1, 55-67.

161. Zallot, R.; Harrison, K.J.; Kolaczkowski, B.; de Crécy-Lagard, V. Functional Annotations of Paralogs: A Blessing and a Curse. Life 2016, 6, 39. [CrossRef] 